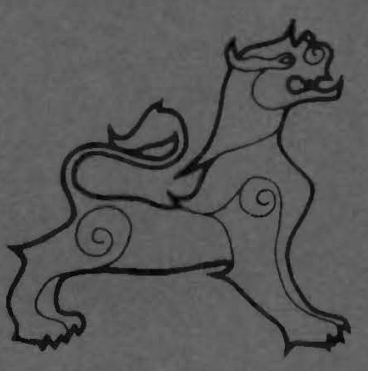

The Afghanistan Council

of

\title{
THE ASIA SOCIETY
}


English translations of some of the new laws promulgated by the Republic of Afghanistan

These laws are published in Dari and Pushtu in the Official Gazette

C ONTENTS

Law of Afghanistan's National oil Company

p. 1

Instructions related to the Regulations Governing

Commercial Activities

p.2

Foreign and Domestic Private Investment Law of

1353 (1974)

p. 6

Licensing Regulations for Private Foreign Traders and Firms in Afghanistan

p.13

Police and Gendarmarie Law

p.19

New Road Traffic Laws

p.24

Graduated Land Tax Law

p. 30

New Land Reform Law of Afghanistan

p. 32

Generic Drugs Law

p. 35

Norms and Standards Charter

p.36

Text of the Money and Banking Law

p.38

Research librarians should take note that these official publications could be valuable for future researchers. The official Gazette is available from the Ministry of Justice in Kabul.

Editors note: The traffic laws were written in German, translated into Dari and Pushtu and then translated into English. We have reproduced them as they came to us in English from Afghanistan.

April, 1975

Updated January, 1978 


\section{LAW OF AFGHANISTAN'S NATIONAL OIL COMPANY}

Following is an unofficial trans. lation of the Law of Afghanistan's Natiunal Oil Company.

'The Law of the Afgliauistan's National Oil Company for the purpose of implementing a natiounil poticy on ofl and initurisl tas. With the object of determining and formulating necessary policies on preservation and development of nil and natural gas resources and also taking measures to make utmost economic use of the saidl resmirces.

Fur the purpose of plumaning and organising all activities pertaining to oil and natural gas.

inel finally for the purmose of unitication and coordmation of the alfairs pertaining to oil aid natural gas throughout the country.

The Republican state of Afghanistan orders the implementation of the provisions of the following law

ARTICLE 1

Arcording to the exclusive or ders of this law and other laws and regulations which wiln be based on the said aints and will be formulated later. The Afghunistan's National Oit Company is establishced as a state enter crise.

\section{ARTICLE 2}

The: Afgheniatun's Nottonal Oil company is legal entity, and kead quartered in Kabul.

The umtimiled ancherities wh The teluted to tiwe tireablent of the Company and other kigh au thorities of the company in line with the instructions of clanse (A) are impirmented with the observance of the following conditions:

1-In sccordance with the provisions of this law end or other cxelusive laws and regulations of the company.

2-In the abrence of the ex clusive laws and regulations of the company, laws and general reyulations of the state will be im lomantro.

FINANCIAL AFFAIRS CHAPTER III

ARTICLE 5

1-All the rapilal and incomes of the Afghamistan'! National Oil Company belong to the state.

2-The company shall draw its iczular and developrnent budget in line with the approval of the rabinet and shall transfer the rast of its inconie to the state.

3-The capital of Afghanistan Nationai Oil Company is compos ed of:

a-Movable and immovable pro perties which belong to the AI ghanistari's National Oil Company in accordance with the approval of the cobinet.

-The state places 500 miltion Afghanis at the disposil of the Afghanistan National oil Company as nfficial capital to start its clivities. Of this capital in the first stage 50 million afghanis sh. in be paid at the time of estab lishe paid at the reat thall be Jisher whe reat propos at of the Afghanisian : No proposalo of the AIghanistan : No

\section{FIRST CHAPTER} DUITIE:

ARTICLE: 3

The Afghanistan's National Oi Comparly curries out the collowing duties:

1-- Proposing general oil and alural gas policy to the state

2-.Planning for the purpose of inplementing the policy mrutioned in clause

3-Provision and preparation of annual work programine of the Compasy and tlic impleticeulation of the programinus approved and sanctioned.

4-Provision and preparation of orilinisy and develupument bud gets of the cumpany and similarly of the iong-terms budgetar plans neressary for the implementation of the afore-mentione plans jind programines of the company.

5-Preparation and exccution of the cooperation agreements and progtamnies with the national companics of ol her states. and branches thercof and simi. larly with private foreign conpanies which have engaged in oil and natural gas affitirs, exiraction industrits.

6-Preparing the ground for and taking of necessary measures in the purpose of bringing ent oif

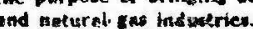

7-Prepuration and inplemen tation of oil vas nesurel con ex-

\section{PAET II}

rovel of the tubinet.
c-The President of the Afthe C-The Fresident of tome Afthe nistan National Oil Company
for the purpose of increasing the capilal of the company can conciude loan agrements within and outside the country with the per. mission of the State. In addition to this, it has the right to issue loan bonds which will be guaran teed by the government

4-incomes:

The Afghanistan National Oil Company shall earn its income from the following sources:

a-Procerds of the sale of oil and natural gos and or other re lated products and the services which the company renders ag. ainst payments.

b.- Dy the conclusion of oil con. tracts with forcigu companies, production licences, leasing fce, ownership fec and fines against
commitments not carricd out provided in the contract.

5-Banking Transactions:

As it is requited the Afghanis. Ian National Dil Company shall open its accounts at D'Afghanis. tan Bank and its related branches and shall make all its local and foreign transactions through $D$. Afghanistan Ba:sk

6-Acrounting and autiting -The Afghanisten"- Nation Oil Company in earrying out- its operations shall folluw the mot orn principles and orecedures of ccounting and shall employ qua lified sccountants and uditors to execute the Job.

b-The Ministry of Pinatire ahall easign its auditors to audit the eccourts of the Afghanistan $\mathrm{Na}$. tional oil Comperiy. port progranmes and in case of ecrsuty the impoit of coude vil and natura! gas.

8--Drawing up and implenentation of urgent traning progis mine for the personicl ateriled by the company so that an adequate number of professional and lech nicat perso nel coutu be nutde available to curry out various opcrations of tite Afghanistan's Na tional Oil Company.

9-Fornulation and Prepatation of laws, resulutiuns and bills re latihg 10 oil and natural 835 . 10-Collection, analysis of pu blication and finally distribution of expert and technicit inlorma. tion about the documests pertinent to the activities of oil and natura! gas.

\section{CIAPTER 11}

\section{ARTICLE 4}

In accordance with the provi sions of this law and the exclusive Jaws and regulutions whic will be formulated later the $\Lambda$. ghanistan's National Oii Company has liwo kinds of authotities: A-limited authorilirs, B-Unlimited authoritics,

$$
\text { A-Limited anthorities: }
$$

Limited authorities are related to those activities whose performance rcquires besides the pro posts of the cotupany the app roval of the Miniater of Mines nad

C-In eddition, on the writte arder of thi loiule shisiviter Afghanistan Natiunal Oil Com pany's accounts in an extraordin. ary case shall be audited by joint cominittce consisting represculatives from l'ost Auditing Bureau of the Prime Mtinistry, Pinance Ministry and the results so oblained shall be submitted to the Cabinct. CHAPTER IV

AITICLE 6

a-The organisational plan of the Afghanistan National Oil Company in accordance with the provisions of this luse shull be drawn up according to the requ irements of the petroleum industry by the President of the rom puny and will be stumitted to the cabinet for approval and sanction. b-The President of the Afghanistan National Oil Coinpany hall be of ministerial rank and shail be appointed on the propasat of the Minister of Mines and Industries, approval of the cabi net and sanction of the President of the state.

c-For the purpose of consulta lion on plonning and operation of the Afghanistan . National $\mathrm{O}_{\mathrm{i}}$ Company necessary facilitics and needed personncl shall be placed at the disposal of the coinpany y the goverument.

d-Within three montbs after the establishment of the Afghnnstan National Oil Company the Presitent of the Cenipany shall submit to the cabinet for aporoval the organisational plate of the company including the job descri ptiona of the departments concer ned. the budget of the company

Industries and of the r.ahinet. I-turmulation of buiget alld advancement of tlis annual pro grams of the company in addition to the long term programmes. 2-Pieparation and formulation of specifird latis for ofticiials contractors, and workers

3-Alteration of the internat organisational stivcture of the company.

4-increase and aniendment of the ritrisal of the rumputuly for the purpose of boosting up the operations and the assigned tasks of thr company including the

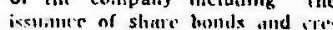
dit honds and atso the preserva. tion of monetary reserves. 5-The estabilishment of hran ch firms. totally owned by the rompany. and or with the finan cial purticipation of other local and forriglu conpanies whose shares should not exceed 49 per cent of the original capilal G-Conclusion of financial. prospecting. extrarting. Iransfer 
INSTRUCTIONS RELATED TO THE REGULATIONS

GOVERNING COMMERCIAI ACTIVITIES

Published in Official Gazette No. 35

(1353)

For the purpose of the application of the provisions of the Regulations Governing Commercial Activities and in order to provide facilities for trade enterprises, these instructions are established in accordance with the provisions of Article 20 of the Regulations.

1) In accordance with the provisions of Article 10 of the Governing Commercial Activities trade enterprises are required to obtain the permission of the Ministry prior to the importation of goods.

Permission of the Ministry may be procured in any one of the following ways, whichever is easier for the trade organization:

a. Trade enterprises, personally or through their representatives, should present three copies of the pro forma invoice or draft of the purchase contract or similar documents to the Presidency of Foreign Trade in Kabul or to the Trade Directorate in the provinces and, on one copy, the registration and stamp of the office will be obtained. When clearing the goods from the appropriate customs house, (they) should attach this stamped copy to the other documents submitted to the customs house.

b. Trade enterprises shall send three copies of the pro forma invoice or copy of the purchase contract or similar documents to the Presidency of Foreign Trade in Kabul or to the Trade Directorate in the provinces by registered mail.

The appropriate offices of the Ministry of Commerce, after stamping and registering, will send one copy to the Statistics Department of the Ministry of Commerce located in the appropriate customs house.

The trade enterprise, when clearing their goods, will go to the statistics office and receive this stamped copy from that office.

c. Trade enterprises outside the country, which are involved in purchasing goods, personally or by their representative, should send three copies of the purchase contract, pro form invoice or similar documents by air mail to the address of the Foreign Trade Presidency in the capital or to the Trade Directorate in the provinces where their goods are to be cleared.

The appropriate department of the Ministry will immediately, after registration and stamping, send one copy to the statistics Department of the appropriate customs house so that, Wile the goods are being cleared by the trade enterprise, the stamped copy should be delivered to the enterprise.

Barter contracts, the stages of which are completed through the Ministry of Commerce, are not bound by the provisions of Article I of this instruction.

2) The pro forma invoice, draft purchase contract or similar documents that trade enterprises, in accordance with the above Article $I$, submit or mail to the Ministry should, in accordance with trade procedures, contain the following information - quality, quantity, price and payment and delivery terms.

3) In accordance with Article 14 of the Regulations Governing Commercial Activities, trade enterprises which export goods should send a copy of the sales contract, or invoice or, in case the exportation of goods takes place according to consignment terms, the appropriate documents to the Piresidency of Foreign Trade in Kabul or to the Trade Department in the provinces within a week after the s. export.

Exporters and importers of fresh fruits are not bound by the provisions of this instruction and, as before, their responsibility ends when their export or import is recorded by the statistics Department of the appropriate customs house. 
4) Ministries, government offices and public institutions, which are involved in import or export of goods are also subject to the provisions of this instruction.

\section{REGULATIONS GOVERNING COMMERCIAL ACTIVITIES}

ARTICIIS 1. The object of these regulations is to regulate commercial activities and to coordinate them with the other economic programs of the Government and to make better use of foreign exchange for sound development of trade.

2. In these regulations

(a) "Trade Organizations" shall mean individual traders, corporations and government enterprises, established under the Commercial Law, for purposes of trade.

(b) "Licenses" shall mean permits issued by the Ministry of Commerce for commercial activities.

(c) "Ministry" shall mean the Ministry of Commerce of the Republic of Afghanistan.

3. Every trade organization shall obtain a license from the Ministry upon payment of a fee to be determined by the Ministry in order to engage in commercial activities. Such licenses shall be renewable annually.

4. No individual or organization shall engage in commercial activities without possession of a valid license.

Any Ministry, Public Sector or Government Organization which imports or exports goods for purposes other than trade need not obtain a license.

5. Licenses are issuable to individuals who are legally qualified and to corporations and partnerships established under the commercial Law.

6. Under these regulations three types of license may be issued:

(a) License A will be issued to trade organizations which engage in export and import trade.

(b) License $B$ will be issued to trade organizations which engage in the business of commission agents and brokers as between foreign and domestic traders.

(c) License $\mathrm{C}$ will be issued to trade organizations which perform the following services - Banking, Insurance, Transport, Forwarding, Consultancy and Travel and Tourist Agency Business.

Any commercial activity not covered by the above categories will be determined by the Ministry and notified for the purposes of licensing. 
ARTICLES 7. A trade organization may be issued all three types of licenses referred to in Article 6.

The issue of licenses to foreign trade organizations will be governed by the "Licensing Regulations for Private Foreign Traders and firms in Afghanistan."

8. No trade organization shall engage in any commercial activities outside the scope of its license or licenses. All goods and commodities which a trading organization intends to import or export will be itemized in the licenses issued to that organization.

9. No trade organization shall have commercial dealings with a country with which trade is forbidden. Similarly, no trade organization shall undertake commercial transactions contrary to any trade agreements, trade protocol or payments' agreements concluded by the Republic of Afghanistan with other countries.

10. Every trade organization shall obtain the prior permission of the Ministry before placing orders or concluding contracts of purchase for import of goods. Such prior permission may be obtained upon submission of a copy of the pro forma invoice or contract with a covering letter to the Ministry, personally or through an authorized agent.

Ministries, government departments and public institutions and enterprises shall also be subject to this Regulation.

11. If any trading organization imports goods without obtaining the prior permission of the Ministry as required by Article 10 in addition to therans duties and charges, a fine of $10 \%$ of the total value of all customs duties and charges levied on the consignment, w11l become payable.

12. All goods not subject to customs duty and charges, imported in violation of Article 10, shall be subject to a fine consisting of 58 of their invoiced value.

13. Exports shall not be subject to prior permission of the Ministry, provided they do not belong to the category of "prohibited exports." Lists of "prohibited exports and imports" will be published from time to time by the Ministry.

14. All trade organizations engaging in export trade are obliged to officially submit copies of sales contracts and invoices and if the goods are being exported on a consignment basis, all documents concerning quality, quantity, price, description, delivery and any other relevant information concerning these goods to the Ministry within one week of their export from Afghanistan. Failure to do so will make the organization liable to a penalty of 58 of the sale price of the goods exported.

15. Import or export of goods for purposes other than trade and samples shall not be subject to the requirements mentioned in the above Articles. 
ARTICLES 16. If a trade organization cancels or otherwise invalidates a sales contract, information of such cancellations or invalidation shall be given to the Ministry within one month of its occurence.

17. Those trade organizations which have entered into valid contracts of purchase for import and have placed orders before the enforcement of these regulations, shall send one copy each of every pro forma invoice or purchase contract to the Ministry within two months from the publication of these regulations. Failure to do so will make them liable to the penalties of Articles 11 and 12 .

18. Those trade organizations which have already entered into valid sales contracts for export, including sales by consignment, before the enforcement of these regulations, shall send one copy each of such contracts or consignment notes, to the Ministry, giving full particulars such as description, quality, quantity, price, delivery and all relevant information relating to the goods exported within two months of the publication of these regulations. Failure to do so will render them liable to the penalties of Article 14.

19. The Ministry shall be the sole authority for administering these regulations. Any authority now being exercised by any other ministries or Government Departments are hereby transferred to the Ministry.

Technical specifications and requirements relating to technical and specialized goods shall be laid down by the relevant Ministries and departments.

20. In order to enforce these regulations, the Ministry will prepare a separate manual of instructions.

21. These regulations will be enforced after publication in the official Gazette. 
FOREIGN AND DOMESTIC PRIVATE INVESTMENT LAW OF 1353 (1974)

This is an unofficial publication of the approved English language version of the new investment law. The titles to the articles appear only in the English version and are not part of the law. In the event of a difference in interpretation between the English version and the official Dari version, the Dari version shall prevail.

\section{N D E X}

Article I
Article II
Article III
Article IV
Article V
Article VI
Article VII
Article VIII
Article IX
Article X
Article XI
Article XII
Article XIII
Article XIV
Article XV
Article XVI
Article XVII
Article XVIII
Article XIX
Article XX
Article XXI
Article XXII
Article XXIII

Appendix A
Purpose

Characteristics of Desirable Investments

Qualifications of Private Investments

Scope for Private Investment

Benefits and Prerogatives

Proper Use of Benefits

Capital, Profit and Debt Service Repatriation

Licensing Fees for Patents and know-how

Non-discrimination According to Nationality of Capital

Evaluation of Investment-in-kind and Intangibles

Repatriation of Expatriate Salaries

Equal Treatment of Foreign and Afghan Nationals

Accounting and Auditing

Sale of Shares

Transfer of Proceeds of Sale of Shares and Liquidation Limitation of Foreign Equity

Government Purchase of Local Products

Expropriation

Disputes

Investment Committee Composition and Operation

Single License and Import-Export Restrictions

Abrogation of Former Law and Retroactivity

Effective Date of Present Law

Schedule of Court Service Fees for Approved Investments

$\star * *$

June 10, 1974 
The purpose of this law is to encourage, protect, guide, and control private investment for the creation and expansion of industries, and to provide necessary collaboration between public and private investment for the purpose of the progress, coordination, and balanced development of the national economy.

Article II. $\quad$ Characteristics of Desirable Investments

For the purpose of increasing national income, private investment shall be based on a majority of the following bases/characteristics:

1. Maximum use of Afghan raw materials,

2. Maximum use of Afghan manpower,

3. Import substitution,

4. Increase in quantity and value of exportable items,

5. Satisfaction of the common needs,

6. Use of Afghan industrial products, and

7. Maximum value added.

Article III. Qualifications of Private Investments

Private investments by real persons or legal entities shall benefit from exemptions and favorable treatment and shall be obliged to fulfill their obligations as specified in the present law, provided that the following conditions are met:

1. The investment should have been officially approved and registered by the Investment committee according to the provisions of the present law.

2. The investment should be made by real persons or legal entities authorized to conclude and execute such transactions.

3. The books of account of the investment should be audited annually at the expense of the investor by an independent auditor who meets international standards and who is acceptable to the Ministry of Finance of Afghanistan.

4. The investment is within the scope of the field of investment and projects determined by the Investment Committee to be appropriate and acceptable for private - investment under the present law.

Article IV. $\quad$ Scope for Private Investment

The Investment Committee shall meet at least once a year to determine the list of approved projects and shall cause the list to be published at least once a year in the local press.

\section{Article V. Benefits and Prerogatives}

Investments that have been approved by the Investment Committee according to the provisions of this law shall beneift from the following exemptions and special treatment:

1. Exemption from taxes on all income of the company for a period of four consecutive y.ears beginning with the 
year in which the first sale of goods or services of the approved investment occurs.

2. Exemption from personal income tax and corporate tax on all dividends for four consecutive years beginning with the year in which a dividend is first distributed, provided that the tax exemption shall in no event extend beyond the seventh year from the date of approval of the investment.

3. For projects that are going to be established outside of Kabul Province, the duration of the exemptions referred to in paragraphs (1) and (2) of this article shall be increased by two years.

4. For capital goods, spare parts for replacement, raw materials, and semi-finished goods not produced in the country and necessary for the establishment or current production of the approved investment, the following favorable customs duties are applicable:

Capital goods: exempted (in accordance with Article 26 of the Customs Law).

Spare parts: ten percent (on the basis of the invoice for the goods at the clistoms port or the unit price). Raw materials and semi-finished goods: twenty percent maximum (on the basis of the invoice for the goods at the customs post or the unit price).

Within the twenty percent maximum rate, the customs duties for individial raw materials and semi-finished goods shall be determined and announced by the Investment Committee at least once a year prior to the beginning of the year on the basis of their classification and considering the custom duties on similar imported goods and the provision of Article II of the present law. Passenger automobiles, ordinary trucks, ordinary construction materials, and office furniture shall in no event be exempted from the customs duty.

Imports that come under the above exemptions or reductions must be registered by the customs presidency of the Ministry of Finance and a copy of the registration must be sent to the Chairman of the Investment Committee.

If a dispute arises as to the interpretation of the present law with respect to whether a specific import is to be regarded as essential, such dispute shall be considered in the first instance by the Investment committee, which shall express its views. If the Investment Committee opinion is adverse to the petitioner, he may appeal to the Primary Commercial Court in Kabul whose decision shall be final and binding .

5. Approved investments are exempt from payment of sukuk taxes, registration fees, and other legal fees levied by the court in connection with the preparation of commercial and judicial documents and deeds related to bank transactions. However, investors are required to pay court service fees for the completion of procedures necessary for the abovementioned documents and deeds at the agreed upon rates in the schedule in Appendix $A$ of the present law. 
6. Interest on foreign loans that are part of an approved investment is fully exempt from income taxes.

7. Products of an approved investment shall be exempt from payment of export taxes according to the provisions of the Customs Law, provided that such products are permitted to be exported.

\section{Article VI. $\quad$ Proper Use of Benefits}

Proper use of the exemptions and prerogatives provided in the present law shall be controlled by the Investment Committee. In case of proof that an investor abuses the exemptions and prerogatives, the Investment Committee has the authority to withdraw these benefits partially or entirely.

Article VII. Capital, Profit, and Debt Service Repatriation

Capital, profits accruing to foreign investors, and interest installments on loans received from abroad may be freely repatriated in the original foreign currency on the basis of the Da Afghanistan Bank free market rate in accordance with the following conditions:

1. Payment of principal and interest to the extent of the obligation in the credit agreement.

2. Profits of the foreign investment at the end of any fiscal year after submission to the Ministry of Finance of an auditors certificate in accordance with Article XIII of the present law.

3. Registered foreign capital and such reinvested profits as shall have been registered after five,years from the date of approval of the investment at an annual rate not to exceed twenty percent of the total foreign capital invested and registered.

4. With respect to the imposition of foreign exchange controls, the foreign investors shall enjoy equal rights with Afghan nationals regarding the availability of foreign exchange.

Article VIII. $\quad$ Iicensing Fees for Patents and know-how

The purchase price of licensing fee for patents or know-how that are part of an approved investment may be repatriated in accordance with the legal obligation to make such payments, provided that such purchase price or licensing fee has been approved by the Investment Committee as constituting a part of the approved investment.

Article IX. Non-discrimination According to Nationality of Capital

There shall be no discrimination between Afghan capital and foreign capital invested pursuant to this law as regards facilities, prerogatives, tax and customs obligations, keeping of accounts, and judicial and arbitration procedures.

Article $\mathrm{x} . \quad \quad$ Evaluation of Investment-in-kind and Intangibles

Investments in kind and intangible assets shall be evaluated at current international market prices. In case of disagreement, the valuation shall be done by an independent professional appraiser acceptable to the Investment committee. 
Foreign personnel of approved enterprises may repatriate up to sixty percent of their income net of taxes through Da Afghanistan Bank at the latter's free market rate of exchange.

Article XII. Equal Treatment of Foreign and Afghan Nationals

Foreign companies, investors, and personnel within the scope of this law shall be subject to the same obligations as similarly situated Afghan nationals with réspect to rights, taxes, customs duties, and other fiscal obligations.

Article XIII. Accounting and Auditing

Enterprises within the scope of this law are required to maintain books of account, a balance sheet, and a profit and loss statement which must be audited annually by an independent auditor who meets international standards and is acceptable to the Ministry of Finance of Afghanistan. Copies of the auditor's report shall be submitted annually by the private enterprise to the Ministry of Finance and the Chairman of the Investment Committee.

Article XIV. $\quad$ Sale of Shares

Shares of approved investments may be freely sold to any Afghan or foreign national, provided that such sale should be within the limit set up in Article XVI of this law and in accordance with the Commercial Code of Afghanistan; however, these shares cannot be sold to a foreign government or governinental agency.

Article XV. Transfer of Proceeds of Sale of Shares and of Liquidation

The proceeds of the sale of shares of foreign nationals in an approved investment sold to the Government of Afghanistan or to Afghan nationals may be transferred through the Da Afghanistan Bank at the latter's free market rate of exchange in accordance with Article VII of this law.

In case of liquidation or bankruptcy, after the completion of the required legal procedures therefor, the remaining net assets belonging to foreign nationals after the liquidation are transferable abroad as provided above.

Article XVI. $\quad$ Limitation of Foreign Equity

Foreign investment under the present law shall be made in the form of a joint venture with Afghan capital and the share of foreign investment in a given investment cannot exceed forty-nine percent.

Article XVII. Government Purchase of Local Products

Government departments and enterprises are required to purchase their necessary supplies and services from enterprises established under the provisions of this law, provided that such supplies and services produced in Afghanistan shall not be substantially different than similar imported goods and services and that the price of the local goods and services shall not be more than fifteen percent higher than importable equivalents.

Article XVIII. $\quad$ Expropriation

Property of an approved investment cannot be expropriated except as provided for by the applicable law and upon issue of an order of the competent court. Expropriation of the property of an. approved investment can be carried out only 
in the public interest and after compensation made according to the provisions of the law.

Article XIX Disputes

Except for the case mentioned in the foregoing article, disputes arising from the application of this law between the Investment Committee and foreign nationals shall be settled in accordance with the Convention on the Settlement of Investment Disputes Between States and Nationals of Other States, provided that the Investment Committee and foreign investor agree to do so. Such agreements shall be transmitted to the Secretary General of the International Center for the Settlement of Investment Disputes as provided by the above Convention. In the absence of agreement by the Investment Committee and foreign investors to submit to arbitration as provided above, disputes between the Investment Committee and foreign investors shall be settled as follows. Each party shall appoint one arbitrator, who shall then jointly select a mutually-acceptable third arbitrator within thirty days. If within this period a third arbitrator is not selected, or if the second arbitrator is not appointed within thirty days after the other party has appointed and given notice of its arbitrator, then such arbitrator or arbitrators shall be appointed by the Secretary General of the above-mentioned International Center.

The arbitral tribunal composed of the above three arbitrators shall determine its own rules of procedure and shall assess costs between the parties.

Decisions shall be taken by majority of the arbitrators.

The arbitral award shall be in writing, shall contain a statement of the reasons on which it is based and shall be published in the Official Gazette.

The arbitral award shall be accepted by the parties as the final adjudication of the dispute.

Article $x x$. Investment Committee Composition and Operation

The Investment Committee shall be composed of the following ministers or their authorized representatives: The Minister of Planning, the Minister of Commerce, the Minister of Mines and Industries, the Minister of Finance, and the Minister of Agriculture and Irrigation. The Minister of Planning shall serve as permanent chairman of the Investment Committee. In his absence, the Minister of Commerce shall act as chairman.

The Investment Committee shall convene at least once each month to consider investment applications and related matters. Decisions of the Investment Committee shall be by simple majority vote of the members of the committee. The Investment Committee shall prepare, for submission to the government, the regulations necessary for achievement of the goals established in the present law. The Investment Committee shall undertake selected and effective measures in accordance with the provisions of this law for the fulfullment of its objectives.

Article XXI. Single License and Import-Export Restrictions

The license issued on the basis of final approval by the Investment Committee shall constitute the only license required under the Law of the Republican Government of Afghanistan for an approved investment. The approved investment cannot export goods which are not of its own production nor import goods other than those necessary for its own production.

Article XXII. Abrogation of Former Law and Retroactivity

1. After the effective date of this law, the Foreign and 
Domestic Private Investment Law of 1345 shall stand abrogated.

2. The investments which have been approved under the terms of the Foreign and Domestic Private Investment Law of 1345 are obliged to offer foreign shareholdings for sale on the basis of the provisions of Article XVI of the present law.

Article XXIII. Effective Date of Present Iaw

This law shall enter into force after publication in the official Gazette.

\author{
A P P EN D I X A \\ Schedule of Court service fees \\ for approved investments
}

Registered Amount

Up to Afs. $1,000,000$

From 1,000,001 to

$5,000,000$

From $5,000,001$ to $10,000,000$

From $10,000,001$ to $15,000,000$

From $15,000,001$ to $20,000,000$

From 20,000,001 to $30,000,000$

From $30,000,001$ to $50,000,000$

Above $50,000,000$
Deeds

Afs. 2,000

Afs. 8,000

Afs. . 20,000

Afs. 40,000

Afs. 60,000

Afs: 80,000

Afs. 120,000

Afs. 200,000
Other Registered Documents

Afs. 1,000

Afs. 4,000

Afs. 12,000

Afs. 20,000

Afs. 32,000

Afs. 40,000

Afs. 60,000

Afs. 80,000 
Unofficial translation pxepared by the Ministry of Commerce, July 1971, - as far as we know this law is still in effect.

LICENSING REGULATIONS FOR PRIVATE

FOREIGN TRADERS AND FIRMS IN AFGHANISTAN

Article 1: All foreign traders, whether real or legal persons, desiring to engage in business in Afghanistan must apply to the Directorate of Licenses in the Ministry of Commerce for issuance or renewal of their commercial licenses. If the application is accepted by the Ministry of Commerce, the license shall be issued by the General Presidency of the Chamber of Commerce for a specified fee.

Article 2: Foreign traders must explain in their application the nature of their activities in detail.

Article 3: Two types of commercial licenses are authorized for foreign traders, Type A and Type B:

a. Type A licenses shall be issued to foreign traders who are trading for their own account.

b. Type B licenses shall be issued to foreign traders who work in exchange for commissions, brokerage fees or other fees from foreign firms.

Article 4: In order to receive a Type A license, the following procedure must be observed:

a. If the merchant is an individual:

1. Submission of a written request and three photos to the Directorate of Licenses of the Ministry of Commerce, and completion of the appropriate forms.

2. Presentation of a certified statement, by a commercial court or by an authorized agency. from the applicant's country, to the effect that the applicant has been engaged in business during the past three years.

3. Presentation of a certificate from the applicant's country that he has not been a judgment debter during the past three years.

4. Presentation of a certified statement from a commercial bank of the applicant's place of residence concerning the financial and commercial credit standing of the applicant during the preceding three years.

The above-mentioned documents must be certified by the 
Afghan Embassy or Consulate in the applicant's country and must bear the initials and seal of the competent department of the Afghan Ministry of Foreign Affairs.

5. The above-mentioned trader must, before the license may be issued, transfer as capital an amount equal to ten thousand United states dollars, or the equivalent in another foreign currency acceptable to the Ministry of Commerce, at the free market rate of the D'Afghanistan Bank.

b. In order for branches of foreign firus to qualify for a license, the following procedure must be observed:

1. Submission of a written request together with a letter of introduction and letter of authorization from the related foreign firm concerning the opening of the firm's branch or agency in Afghanistan, and completion of the appropriate forms.

2. Operating capital for the branch's activities equal to at least thirty thousand United States dollars, or its equivalent in another foreign currency acceptable to the Ministry of Commerce, to be transferred at the free market rate of the D'Afghanistan Bank to the branch's account at the D'Afghanistan Bank before the license may be issued.

3. Presentation of a certified statement, by a commercial court or by an authorized agency from the applicant's country, containing the name, purpose, date of establishment, amount of capital and address of the firm's head office.

4. Presentation of a certified statement from a commercial bank concerning the financial position and credit of the firm.

5. Presentation of a certified statement by the firm guaranteeing the transaction of the firm's branch. These documents must be certified by :the Afghan Embassy or Consulate'in: the applicant's country and must bear the initials and seal of the competent department of the Afghan Ministry of Foreign Affairs.

Article 5: Foreign importing traders possessing a Type A license, who in effect have an actual monopoly quasi-monopoly position are bound by the following: provisions with respect to the sales price of their merchandise, whether sold at wholesale or retail, and shall also be subject to the provisions of Article 8:

a. A maximum selling price for the goods of a trader having attained the above-mentioned position shall be computed on the basis of the export price of the firm or producers, plus transportation cost, customs duty, administrative expenses and fixed profit to be established by the Ministry of Commerce, based on the exchange rate at the time of importation. This price shall be advertised by the trader in his business establishment. 
b. A price list of the above-mentioned trader's goods, which must include a detailed computation and must be based on documents, requires the prior approval of the Ministry of Commerce.

c. If such a trader desires to have his merchanise sold through Afghanistan traders for a commission or fee of such commission, agents shall be fixed by agreement of both parties, and it shall be included in the fixed profit mentioned in subparagraph a. of this Article.

d. Traders subject to this Article are required to submit to the Ministry of Commerce without delay a list containing the names and business addresses of their commission agents, together with the names of items supplied to each for sale.

e. Should any change occur in the list of commission agent's or the items supplied to them, such change must be reported in writing to the Ministry of Commerce.

f. In the event of concealment, deviation or fraud concerning the export price of the firm or producer, or with respect. to the price of direct or indirect sales or the appointment of commission agents, etc., by a trader subject to this Article, and if such misconduct constitutes a punishable offence, the violator shall be subject to an appropriate fine as prescribed by the Ministry of Commerce, and in the event of repetition of such offense the case shall be lodged with the court.

Article 6: Foreign importing traderspossessing a Type A license, who have attained a position of actual monopoly or semi-monopoly shall be determined by the Ministry of Commerce and a list of their names advertised every six months.

The matter shall also be formally notified to them.

Article 7: With respect to their importing activities, foreign traders possessing Type A licenses are permitted to import only products of their own country. Foreign traders who are citizens of one country may not import goods produced in another country.

Article 8: A list of merchanise, based on the type and quality of commercial imports, which foreign traders are not permitted to sell at retail shall be prepared and announced by the Ministry of Commerce.

Article 9: The following procedure is prescribed for obtaining a Type B license:

a. Submission of a written request and three photos to the Directorate of Licenses of the Ministry of Commerce, and completion of the appropriate forms.

b. Submission of a letter of introduction from the foreign firms for whom the applicant is acting as commission agent, together withi all relevant agency contracts, to the competent of the Ministry of commerce for registration and approval. The above-mentioned letters 
of introduction must have been certified by the Afghan Embassy or Consulate in the applicant's country and must carry the initials and seals of the competent section of the Ministry of Foreign Affairs.

Article 10: The holder of a Type B license is required to report, in writing, any subsequent changes in the above information to the competent section of the Ministry of Commerce without delay. This must be accompanied by a letter from the firm or firms represented.

Article 1l: Should one or more of the firms mentioned in b. of Article' 9 dismiss its particular commission agent, the matter shall be reported by such commission agent, in writing. and without delay, to the Ministry of Commerce, accompanied by a letter from the firm.

Article 12: All holders of Type B licenses are considered commission agents or fee agents, and are required to enter the fee or commission for each transaction separately in their books and pay tax on their annual income according to the income tax law of Afghanistan.

Article 13: If a foreign trader holding a Type B license does not enter his fee or commission in his books or should his books and accounts not be acceptable to the Afghan tax authorities, the tax liability of such person shall be determined, as is customary, on the basis of gross turnover. The sum of the prices of imported goods entered on invoices issued by foreign firms dealt with during the year shall constitute the gross turnover of such trader.

Article 14: If a foreign trader holding a Type B license conceals his brokerage fee or commission, or should he commit a fraudulent act. with respect to his commissions or the amounts thereof, the tax shall be imposed upon him according to the tax law, his commercial activities shall be terminated and after the liquidation of his transactions and the payment of taxes, he will be subject to pubishment by the courts.

Article 15: In each fiscal year, after payment on all transactions, foreign traders holding Type B licenses are required to convert in afghanis at least thirty per cent of their net annual income through the D'Afghanistan Bank at the official bank rate.

Article 16: In order to provide security and assurance for the fulfillment of tax liabilities and other obligations of a foreign trader holding Type $B$ license, such trader shall be required, before receiving his license to furnish and submit a bank guaranty equivalent to thirty thousand United States dollars.

Article 17: The activities of foreign traders holding Type B licenses shall be restricted to goods produced in their respective countries.

A commission agent who is a citizen of one country may not engage in commercial transactions involving the export goods of another country.

Article 18: A and B licenses shall be valid for a period of one year. After such period, the license of a foreign trader may be renewed, provided such trader has completely fulfilled all his obligations including payment of taxes and foreign: exchange obligations and other obligations arising under these regulations.

Article 19: Foreign traders in Afghanistan may not assume any other legal identity except such as is provided by the A and B categories of licenses. 
Article 20: A foreign trader may obtain both Type A and B licenses and engage in both fields concurrently, provided, however, that the activities and items of each license are separately and clearly established beforehand, and provided that books and accounts are separately maintained for each field of activity.

Article 21: All real or legal foreign persons engaged in commercial activities in Afghanistan are required to pay taxes according to the tax laws and regulations of Afghanistan.

Article 22: Foreign traders are required to maintain their commercial accounts and books according to the provisions of the Commercial Code, and such books must be maintained in one of the official languages of Afghanistan.

Article 23: The place of residence and the business establishment of a foreign trader shall be located in the city of Kabul. Foreign traders are not allowed to establish offices or maintain representatives in the provinces. They may travel in the provinces subject to the regulations concerning foreigner's travel in Afghanistan. Should a foreignitrader wish to engage in business in the provinces, this may be done only through Afghan merchants or firms and only with the permission of the Ministry of Commerce.

Article 24: Foreign traders are required to execute all external commercial transactions through the authorized Afghan banks.

Article 25: Residence, exit and re-entry visas for foreign traders shall be issued, upon application and on the basis of the license held, after clearance through the appropriate section of the Ministry of Commerce by the Ministry of Foreign Affairs and the Visa Section of the Police Department of Kabul Province.

Article 26: The extension of visas for foreign traders is subject to their licenses and shall be issued each year after issuance of their commercial licenses.

Article 27: Residence visas for foreign employees of foreign traders in Afghanistan shall be renewed each year, based on the guarantee of their employers.

Article 28: Visas for family members and employees of foreign traders shall be issued by the Ministry of Foreign Affairs and Visa section of the Police Department of Kabul Province on the basis of certification by the Ministry of Commerce.

Article 29: Residence visas for foreigners desiring to enter Afghanistan for business study or for the liquidation of prior commercial transactions may be issued for a maximum period of two months. Such persons are not authorized to conclude any type of commercial transaction except business study or the liquidation of prior commercial transactions. Extension of such visas is subject to the approval of the Ministry of Commerce.

Article 30: Foreign traders are required to inform the Ministry of Commerce, in writing, of the cancellation of the contracts of their foreign employees. The released employees must leave Afghanistan within the period announced to them by the Ministry of Commerce.

Article 31: Foreign traders are required to be personally present at their business office in the city of Kabul to execute their commercial activities. 
-Article 32: If a foreign trader desires to leave Afghanistan temporarily he shall be issued an exit permit after presenting guarantè documents designating guarantors for all his liablities and obligations.

However, if he wishes to leave Afghanistan permanently, he shall be issued an exit permit after the Ministry of Commerce has determined that he has fulfilled all his obligations and responsibilities.

Article 33: Foreign traders, members of their families and their employees are required, during their periods of stay in Afghanistan, to observe all laws and regulations in force in Afghanistan. They are prohibited from interfering, directly or indirectly, in the religious and political affairs of Afghanistan. If they should so interfere, in addition to the applicable legal pubishment, their commercial activities in Afghanistan shall be terminated, their licenses revoked and, after the liquidation of their accounts, foreign exchange transactions and tax matters, they shall be expelled from the country.

Article 34: All previous laws and regulations pertaining to this subject shall be invalid as of the date of entry into force of the present regulations.

Article 35: These regulations shall enter into force two months after the date of their publications in the Official Gazette. 


\section{POLICE}

3: Duties of Gendarmarie:

The gendarmarie pertorms the ollowing duties:

1-Patrolling and guarding the bounclaries of the countiy and ensuring security and order on the borders for consolidating the liational sovereignty.

2-cont:olling the departure and arrival of the people at the borders, river and airports.

3 -Detccive pursuit at the frcistiers of the country.

4-Prevention of smuggling, rontraband goods and goods unlier the government munopoly.

5-Taking appropriate ineasures during novements against the principles of the national sovercignty or when it is being violated.

6-Performing as security patrols at the borders at the time the ariny enters the war.

The type of cooperation of gendarnarie with the army under such situations will be regulated through rules and regulations.

7-Patrolling the border traffic and contiol of passage documents.

8-Delivery or handing over of persons. goods and animals in accordance with legal instructions of the authorised departments.

9--Estabiishing contact with border police of neighbouring couniries on the basis of interna. lional treaties and borter

*

* PART II

regime agrecments.

10-Interrogation and pursuit of criminal actions at the specified border area, notifying the local police by all means possible and reference of preliminary investigation to the authorised departments.

This provision does not hinder the completion of interrogation of crimes, especially at the frontier, such as smuggling, violation of passport and frontier violations.

\section{CHAPTER. IV AUTHORITIES}

\section{ARTICLE 7}

1-Police shall perform duties within the area assigned to it in accordance with the authorities contained in this law and state laws.

2-Police of one area can take action in another area under the following situations:

A-If the police of one area demand the cooperation of the police of another area.

$B$-If no police are on duty in the area.

C-If the arrest or pursuit of suspects, accused, or convicted require, hasty actions.

D-If the perșon having sustained a loss demands the hclp of the police and the police of the area are at a distance from the place of incident.
In the situations contained in the above clauses the police immediately inform the police on duty about their actions taken.

3 - A police of an area can be transferred to another area temporarily at the proposal of the police commandant of the province or at the agreement of the governor.

The police contingency of one province can be assigned temporarily to another province at the proposal of the Police and Gendarmarie Commander in Chief and approval of the Minister of Interior. Emergency pursuit is an exception to this provision.

4-Separate units of police, both in the capital and in the provinces, can be set up when deemed necessary at the proposal of the Interior Minister and appro val of the government.

\section{CHAPTER V}

Resorting to compulsory measures:

\section{ARTICLE 8}

Police can resort to application of the following compulsory measures:

2-Stopping the people for determination of their identity.

3-Making onc leave the location.

4-Summoning.

5-Financial punishment.

6-Putting under detention.

7-Searching of persons, and goods and entry and search of houses.

8-Taking the goods under custody.

\section{ARTICLE 9}

Notification and warning:

For the purpose of maintaining security and public order police can issue the following notifications either written, oral or through signals.

1 -Notification allowing execution of an action.

2-Notification barring from an action.

Also police can, for application of these notifications, give warning to the residents, society and ignoring the warning is tantamount to violation of law and is liable to legal pursuit.

ARTICLE 10

Halting for determination of the identity:

For the following purposes police can stop the people to determine their identity;

1-To prevent a danger; prevention, detection and clarification of crime.

2-To control the travelling documents at the borders, river and airports.

If the documents to determine the identity of a person are found to be inadequate in that case the person will be obligated to report to the police office. 


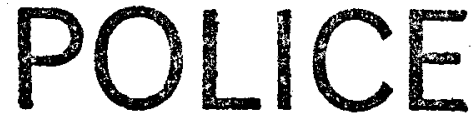

\section{ARTICLE 11}

Compulsory removal:

For fulfilling the following purposseg onlice can force persons to leave their locations:

1-To remove dangers

2-For prevention. detection and clarification of criminal acts.

3-For application of provisions of Criminal Procedural Law.

ARTICLE 12

Summoning:

For fulfilling the following purposes police can take action to summon the persons:

1-For detection, explanation and obtaining information about a specific case with taking into consideration the evaluation of legality of the measure.

2-To ensure the legal demands of legal and real persor:s.

A person who in accordance with the provisions of law and at the request of real and legal persons is summoned by authorised departments but fail to report, police can issue a subpoena to the person whose presence is sought.

\section{AND GENDARMARIE \\ LAW}

PART III

3-For application of the provisions of Criminal Procedural Law.

In fixing a dateline for summoning the vacational and professional obligations and other necessary and vital matters of the person being summoned will be observed.

ARTICLE 13

Financial punishment:

During the following circumstances police can take action for financial punishment of a person:

When the offence of the offender and the consequences of the offence is trivial and the public take no interest in his legal pursuit, with utilisation of the evaluation of the legaiity of the measure, police can take action to punish the offender financially in the form of cash fine not to be more than Afs. 500

If the offender disagrees to the cash fine police is obligated to refer the case to the authorised departments.

\section{RTICTE 14}

To put the persons ander de- tention:

Police can put a person in detention in the following instancès :

1-When the life and safety of a person is being threatened and could not be protected by other ways.

2-When a person has intention to commit suicide.

3-When the determination of the identity is impossible by oth. er ways.

4-When the real or legal persons, in accordance with the provisions of the law, request the detention of the person.

Police inform the enquirer about his actions without delay.

5 -In other instances provided in the Criminal Procedural Law. The duration of detention in the above instances cannot be more than 72 hours.

The person under detention will be informed in writing and without delay about the reason for detention and if the revelation of the secrets is not in question the person under detention will be given permission to inform his relatives or legal defendant.

ARTICLE 15

Searching of persons:

Police in the following instances can search a person:

1-When the person in accordance with the provisions of Article (14) of this law is arrested and put under detention.

2-When there are evidences that the arrested man possesses goods to be protected or confiscated as mentioned in Article (18) of this law.

3-To determine the identity of a person who is unable to present identification documents.

4-When there are evidences that the person possesses goods that can create danger or their possession is illegal..

5-When police are doubtful about the identity of the person stopped.

6-In other instances that ruled by Criminal Procedural Law. The search of females will be carried out by a woman assigned by police. 


\section{POLICE}

ARTICLE 16

In the following instances police can search the godds:

1-When goods belong to the person who in accordance with Article (14) of this law is under detention.

2 - When it is aimed at finding the person or article which in according with Articles (14 and 18) of this law is under detention or confiscation provided there are indications that surh persons and articles are there.

3 -In other instances rulpd by Criminal Procedural Law.

\section{ARTICLE 17}

Entering the house for searching.

Police can search a house in the following instances:

1-To protect the life of a human being against inmediate dangers.

2-When the searching is aimed at locating a person or article which in accordance with contents of Articles (1.j and 18) of this law are under detention and protection, provided there are indications that the person or article sought are in the house

\section{AND GENDARMARIE LAW}

\section{PART IV}

searched.

The conimercial locations when the public are allowed to enter them cannot be considered a house.

3 -In other instances ruled by Criminal Procedural Law.

The purpose of the searching will be notified to the owner of the house only when the actions of police is not endangered by this notification.

ARTICLE 18

Protection or confiscation of goods :

1-For fulfilling the following purposes police can take action to protect or confiscate the goods.

A: To prevent an imminent danger which threatens the public security and order.

B: To prevent actions which would disturb the public security and order provided the prevention of such actions cannot be achieved by other ways.

D: For confiscation of goods which would help to detect the truth and the same goods are in possession of a person, who in accordance with the provisions contained in article (14) of this law is put under detention.

E: To find the substances which are harmful to the health of human being and about which personal report and complaint is made or come to the notice of police.

F: For application of the provisions of the Criminal Procedural Law.

2-Police shall observe in protection and corriscation of the goods :

A: The reason for protection and confiscation of the goods has to be explained to the owner and possessor unless otherwise the proceedings of interrogation is affected.

In any case the copy of verification of the list of goods which are being protected or confiscated will be submitted to the owner and possessor of the goods.

$B$ : Police shall make every possible effort to safeguard the goods under protection or confiscation from wastage and damage.

C: If the goods which are protected or confiscated are perishable and or if maintained for prolonged period may cause decay the sale of the goods are per- missible and if they cannot be sold they will be destroyed at the permission of an authorised court.

$D$ : With achieving the purpose of the protection and confiscation of goods is terminated.

CIIAPTER VI

The authority of police to utilise the enforcement means and its occasions.

ARTICLE 19

The enforcement means of police are:

i-Physical strength

2-Auxiliary means for physical strength.

A: Police vehicles.

B: Water hose,

C. Technical obstructions

D. Police dogs.

E. Police horse

F. Hand cuff.

3-Weapons:

A. Striking

B. Sharped edged.

C. Firing

D. Explosive matters

In using the type of enforcem. ent means police will take into zonsideration the stages reirulated in this article and use where possible' the least incrimminating. 
Article 20

Police can with due considerar tion to the evaluation of legality of measure and after notification of their decision to the other side resort to means of enforcement in the following instances:

First- When hand cuffs are used.

1-Preventing assault against police.

2-Preventing escape.

3-Preventing suicide.

Second. When fire arms are us ed.

1-When police intend to pre vent crime or fclony provided the use of cther means of enforcement as contained in article (19) of this law is not possible or effective.

2-When police intend to detcrmine the identity or arrest of a persoll or persons who has or have escaped, provided:

A. The person is at the state of committing a crime or felony.

$B$. The person is accused of having committed crime or senten- ced.

\section{PART V}

$C$ The person is accused of felony or sentenced.

$D$. The person is sentenced by the court to spend a specific period at the lunatic assylum.

E. The person strongly suspec ted of having committed crime.

$F$. The person is accused of crime or felony and the order of his arrest is issued by an authorised court.

3-When police intend to take effective measure against person or persons who has or have made an attempt to help the fleeing of detainees or prisoners.

4-When police intend to take effective measure against a prisoner who is in possession of an arm or other dangerous means and despite repeated request of police refuses to submit them.

5-When police intend to take effective measure against a prisoner who has rebeled and threatens the security of the prison.

6 -When police intend to effective measure against a group the public security provided the contents of Articles (four) and (2l) are taken into consideration.

7 -When police intend legal defence.

Third. When explosive matters are used.

1-When police' intend to take effective measures against person or persons who has or have te sorted to fire or use explosive means against police.

2-When police intend to take effective measure to ward off the assault of person or persons against whom the use of firing weapons has not achieved desired result.

3-When police intend to take effective measures through utilisation of explosive means against goods provided the contents of the last part of Article (19) of this law is taken into consideration.
ARTICLE 21

In using the fire arms or explosive matters police shall observe the following supplementary conditions except in the state of self defence;

1-To notify the decision of using fire arms or explosive mat. ters against persons or goods.

2-Police cannot use fire arms or explosive matters against persons or goods in such a way as to inflict damage to others.

3- Police cannot use fire arms or explcsive natters against children.

4-The use of fire arms or explosive matters against a crowd is permissible when;

A. The crowd resort to offensive actions or actions disturbing the security and when the use of other means of enforcement by police against persons do not prove effective individually.

B. Notification on use of fire arms or explosive matters has to be made at least by three oral warning and thrce warning shots. 


\section{POLICE}

Miscellaneous Provisions

ARTICLE 22

Taking into consideration the evaluation of legality of measures police can coopurate, for the purpose of protecting the rights of real and legal persons, in the following instances:

1-When complainant demands the cooperation of police provided the rights of the person could not be restored on desired time by authorised departments and if police do not interfere the person's right might be usurped.

2-When there is no complainant or the person is not able to protect his rights.

ARTICLE 23-

When the ministries and public or private institutions resort to actions which is part of - police duties, written approval of authorised department of police has to be obtained.

\section{ARTICLE 24}

The sergeants of class three enrolled in the education institutions of police academy cannot be assigned to duties and operation of police in which the possibility of use of fire arms or explosive matters could be expected.

ARTICLE 25

The police department can, through respective governor's office and with of ficial approval of Interior Minister, acquired through telegram, telephone or by

\section{AND} GENDARMARIE

\section{PART VI}

letter can impose curfews at are perishable police can, after the times when the security and public order is faced with danger for a period not exceeding. more than 48 hours. The curfew can be extended for another 48 hours at the joint approval of Interior Minister and Attorney General and longer than that can be done at the sanction of the President of the State of the Republic.

\section{ARTICLE 26}

As regards the goods found police can take the following measures :

1-Police safeguard the goods found and make a record of it which will be registered in a special book.

2-When need be police cán advertise over radio and in newspapers about the goods found.

3 -The owner of the goods found can collect his soods, when its ownership is determined, after giving receipt to the police office.

4 -If the owner of the goods found does not claim his goods within six months after the advertisement and the goods worth less than a thousand af shanis the police commandant of the location can give the order of the goods to be auctioned, and deposited to the revenue account, of the state.

If the price of goods exceed a thousand afghanis or if the conds are perishable police can, after thorised court, can auction such goods and deposit the sale proc eeds in the trust account.

If the owner of the goods or his authorised representative do not report to the police office within six month after the ad vertisement the sale procecds will be deposited to the revenues account of the state.

5-About the proceeds of the goods following considerations will be observed:

A. Deduction of the expenses for protection.

B. If the founder of the goods is not a member of police force ten per cent of the procecds of the goods will be paid to the founder.

C. The remaining sale proceeds will be deposited in the reve nues account of the state.

6. The members of the police force cannot buy the goods found.

ARTICLE 27

Police is obligated to keep the secrets and information obtained during the execution of their duties, the revelation of which will damage the rights, and prestige of person's or the department's interests, and should not reveal them unless needer legally.

Policemen who have dissoriated from police force due to retireni- ent or other reasons are obliged to respect this provision.

Inter icws with the reporters of radic: and newspanirs on the incidences can be donn within the limit of Press I.aW and other laws and regulations.

ARTICLE 28

Police do not haie the right of strike and demonstration.

ARTICLE 29

Police cannot enter directly into commercial business.

ARTICLE 30

Police cannot use their official authority directly for doing persomal business.

\section{ARTICLE 31}

Police is not oblicated to exrcute order which are contrary to the provisions of the law.

\section{ARTICLE 32}

Those who viclate the provisions of this law are subject to punishment in accordance with the provision of the law.

ARTICLE 33

The govemment can issue regulations for better applicalion of the provisions of this law.

'The Ministry of Interior draws guidelines for beiter application of the provisions of this law.

ARTICLE 3:

This law goes into effect after publication in the Officials Gazette and with tuforcement of this law the provisions contained in the police law effected on 15. Hoot 1351 S.H. are ahirerallod. (IND) 


\section{NEW ROAD TRAFFIC LAWS}

\section{CHAPTER I - General Provisions}

Article 1: This law is promulgated to ensure order and security in traffic and prevention of incidents, and alleviation of dangers which are liable to occur on public roads.

Article 2: The following terminologies in this law shall denote the following meanings .

A. Road Traffic: Passage and halting of human beings, animals and means of transportations on the public road.

B. Public Road: Passage, road, street, avenue, lane and vehicle parks which can be used by everyone either freely or against payment, or otherwise, and is not personal property unless it is set asidesfor public traffic is considered to be public road.

C. Traffic: Human beings who either by their own power, or by other means traverse on the public road.

D. Means of Transport: Means of road transport, or moving on wheels, and propelled by human, animal or motor power.

E. Means of Public Transport: Motor driven means of transport used by individuals against a fixed fare. Bus: and taxis are included in the category.

F. Electrical Bus: A road transport means run by electricity taken from overhead lines, and used for transportation of individuals. Operations of electrical buses will be governed by separate rules.

G. Traffic Signs: Signs made by the police or traffic lights for guidance and regulation of road traffic.

H. Traffic Symbols: Signs installed by the Traffic Department on the public roads permitting, guiding, warning and stopping the traffic through lines, writing or symbols.

I. Pedestrian: Person moving on the public road without making use of transport.

J. Traffic Establishment: Signs, symbols and constructions installed or organized on public roads for gujdance, or convenience of traffic on public roads.

CHAPTER II - Duties of Traffic Police

Article 3: The traffic police are required to regulate, supervise and educate participants in traffic, attend to traffic incidents, ensure security and order of traffic.

Article 4: Police shall halt the participants in traffic in the following instances:

A. When traffic regulations are violated.

B. When checking of documents of the driver, road worthiness of the vehicle is necessary.

C. When a traffic accident has occurred.

D. In other instances when security and order of traffic requires. 
Article 5: In Afghanistan means of transportation move on the right hand side of the road.

Article:6: Participants in traffic are to move on the public road in the way that others are not posed with threat, trouble or loss, and the movements of others are not unnecessarily inhibited.

Article 7: Where sidewalks exist the pedestrians cannot move on the motor road. Where sidewalks lo not exist the pedestrians can use the motor road provided they move on the extreme left side of the road.

Article 8: In the event of existence of a special lane for bicyclists, they are required to make use of it. In places where no such lanes exist the cyclists can use the motor road.

Article 2: Animals can become part of traffic when led by a person capable of doing so. Persons responsible for leading the animals on the road should be familiar with signs and symbols, and abide by those provisions of this law which concern them.

Article 10: Every kind of buggy, animal and human drawn carts should use secondary roads during rush hours, and avoid congested roads. In case of non-existence of secondary roads, they can make use of the public road.

Article 11: . Priority in passage shall be regulated by traffic signs. Abidance by them is required. When two or more vehicles coming from two or more directions come to crosssections, or squares, priority for movement is of the vehicle on the right hand side. When three roads cross each other, priority is given the vehicle moving in a straight line.

Article 12: Driver of means of transport should regulate his speed in a way so that he will have full command of the vehicle at all times, and can stpp it when necessary. In cities and other populated areas where speed limits are not set on signs, it is limited to 50 kilometres an hour. ( 35 miles per hour)

Article 13: Overtaking place from the left, right of way is given ifrome right.

Article 14: Parking shall take place on the right hand side of the street, in the direction of movement, and where parking is not forbidden by a sign.

Article 15: Use will be made of means of warning (honking) when a danger is sensed clearly, and it cannot be averted in any other manner. Undue use of horn, unusual honkings, and repeated and unnecessary honkings are forbidden.

Article 16: No more than three people (including the driver) should be taken on the front seat. Carrying of objerts, either on the front or in the back, inside or outside the vehicle, which obstruct the vision of the driver is forbidden. In vehicles which have their driving wheels on the left side, passengers should not be seated on the left of the driver. Riding or carrying of persons on tool box, steps, the ladder leading on the roof or the roof of the vehicle is forbidden.

Article 17: 1. Means of transport of police, gendarmier, fire brigade, and other symbols having a siren or other warning signal, when they are on urgent and important measures, are exempted from abidance by the provisions of this law to the extent they cause no accidents. 
Article 17 - part 2: Vehicles used in construction or maintenance of roads, or those used in garbage clearing, when necessary while on duty, are permitted to move any direction, and halt on the road wherever necessary. Such vehicles should be marked by special color and signs, and their drivers are required to exercise full caution while performing their duties, and with due consideration to security and order of the traffic.

Article 18: Movement of vehicles shall be regulated by separate regulations.

CHAPTER IV - Licenses

Article 19: Any means of transportation which use the public road should be in possession of registration and in possession of licenses from the Traffic Department. Owners or drivers shall not leave on road, or put at the disposal of others for driving vehicles" which lack necessary equipment and legal requirements.

Article 20: 1. The Traffic Department after examining customs, tax, and other state dues documents, and having assured itself of technical fitness of parts and the whole of the vehicles shall issue registration. 2. Owners of motor driving vehicles are required to renew their registration after the completion of the period inscribed on the document.

Article 2l: Transference of ownership, changing of the engine, chassis, or change of color of the vehicle shall take place only on the permission of the Traffic Department and shall be recorded on the ownership and road permit documents.

Article 22: All vehicles must have official license plates, as well as for supplementary vehicles, when moving on the public road.

Article 23: 1. The driver of means of transportation when driving on public road must be in possession of a driving license for the type of vehicle he drives. 2. Driving license is given to all those who are 18 or above, after passing health and driving tests, and meeting all other legal requirements. The expiration date of the license shall be noted on it.

Article 24: The holder of the Regular Driving License can drive on roads within Afghanistan and the International Driving Licenses which are given in Afghanistan can also drive motor vehicles in Afghanistan.

Article 25: Learning drivers can use the road only when using special vehicles and when accompanied by an authorized driving teacher. The teacher is considered as the driver, and is responsible for the driving.

Article 26: Distribution of road permits and driving licenses shall be governed by other regulations.

Article 27: The driver of motor driven vehicles is required to put on the appropriate lights when darkness falls, or fog obstructs the view. The front lights should be dimmed when vehicles approach from the opposite side.

Article 28: 1. All technical parts and equipment of motor driven and other vehicles should be in proper operational condition and free of defects. 2. Equipment and $\therefore$ accessories of the motor driven vehicles shall be governmented by other regulations. 
Article 29: Real or legal persons using vehicles for transportation of passengers are required to obtain special documents for city or inter-province operations from the Traffic Department, apart from acquiring of documents already provided for in this law.

Article 30: 1. The driver shall not carry loads exceeding the caparity of the vehicle. 2. The means of public transport are not allowed to carry more passengers than the ascribe number. 3. The traffic police can, when overcharging of fares is found, fine the violator of the rule.

Article 31: 1. The driver cannot take loads which overstretches the front seat or the mudguards of the vehicles. In no case should the width of the load exceed the width of the vehicle. 2. The limitation mentioned in clause one of this article shall not be imposed when the condition, the nature or the construction of the cargo does not permit division provided such cargoes are carried on supplementary vehicles. In the 'event the length of the cargo is more than 20 metres a special permit for its carriage should be acquired before its transportation.

Article 32: In the event a motor driven vehicle develops unexpected technical default on the public road, for the convenience of others it should be moved away from the path of traffic.

Article 33: Transportation of passengers and cargo by motor driven and other vehicles shall be regulated by other regulations.

CHAPTER VI - Responsibility of Individuals in the Event of Traffic Accidents

Article 34: Drivers involved in accidents which cause injury or that should halt immediately the means of transport on the scene of the accident and shall not change the position of the vehicle or the scene of accidents until studied by the police. In case the accident causes material loss, when the vehicle can be moved to the extreme right of the road and away from flow of traffic.

Article 35: 1. Those involved in traffic accidents are ordered to halt after the occurance of the accident unless for acceptable reasons the temporarily depart from the scene. In such case they are required to report to the police the accident as soon as possible. 2. The driver of the vehicle causing the accident, resulting in injury is required to help theininjured, and when necessary take them to the hospital or Public Health Centers.

Article 36: No motor driven means of transport can enter the public road unless insured beforehand. Insurance of motor driven means of transport shall be regulated by law.

\section{CHAPTER VII - Miscellaneous Provisions}

Article 37: 1. The flow of traffic is regulated by police, lights, signs, lines or other necessary means. Instructions and guidance of police supercede all other means. 2. Participants in the traffic are required to follow signs and other means of guidance in the area unless otherwise directed by the police in the area. Installation and organization of traffic guidance apparatus shall be regulated by special regulations.

Article 38: Nobody is entitled to drive or move a vehicle which he does not own or of which he is not the driver without the permission of the person in possession of itc..... $u$ except police officers, and only when performing official functions, and in accordance with the provision of the law. 
$\therefore \therefore:$ Article 39: Nobody shall create an obstacle on the road, or close it through abnormal way of moving or parking vehicles or placing other things, construction or demolishing. Construction work on public roads can take place after acquiring permission from the traffic department.

Article 40: Installation of advertisement, portraits, or plates similar to those of traffic signs which might cause misunderstanding of drivers or obstruct view, and installation of colored light adjoining traffic lights which might cause confision is forbidden.

Article 4l: 1. Installation of warning signs, or signs permitting or preventing driving, guidance and delineation of roads are duties of the traffic department in the cities. 2. Construction of roads in accordance with requirements of the locality, and their repair, are creations of traffic establishments are duties of construction and highways. 3. Making or installing traffic signs and other traffic related establishments anywhere shall be done in consultation with the traffic department.

\section{CHAPTER VIII - Punitive Provisions}

Article 42: The court can prevent or deprive the person committing a traffic crime of the right of driving in addition to the punishment it will order for the crime committed. Similarly, the ban on driving of special kinds of motor driven means is within the authority of the court.

Article 43: Withholding the right of driving for three months in case of repeated violation of the orders of this law is within the authority of the Traffic Department.

Article 44: Anyone who drives a vehicle on a public road without having a driving license will be imprisoned from one week to 40 days or fined accordingly. If the owner or the possessor of the vehicle gives permission to a person to drive his car, knowing that he has no driving license, he will be punished to pay 2,000 afghanis.

Article 45: Driving in the state of drunkness is a crime. The person who commits such an offense will be imprisoned from six months to one year or fined between 12,000 and 24,000 afghanis.

Article 46: The driver has no right to drive a vehicle if he has no registration or lawful license plate. The driver will be imprisoned from one to three months or fined 2,000 to 6,000 afghanis. Only the distance from the border to the place of getting customs due is not included in this order.

Article 48: 1. A person who is making use of a motor driven means without the permission of the owner or possessor will be imprisoned from one week to one month or fined accordingly. 2. If this action results in an accident, the person will be punished for the accident and given the punjshment included in the first clause of this article.

Article 47:1. If a person interrupts the traffic during the night by parking a vehicle on the public road without lighting traffic signals and making necessary arrangements and endangers the traffic security, he will be imprisoned from one to three months or fined from 2,000 to 6,000 afghanis. 2. If this action results in an accident, the person will be punished for the accident and given the punishment included in the first clause of this article. 
Article 49: If the person making an accident resulting into killing or severe injuries flees the scene of the accident, he will be punished by imprisonment from six months to one year or fined equally. This is in addition to the punishment caused by the accident.

Article 50: The person who purposely interrupts the security of the road resultihg into casualities and material damage of the road participants will be punished in accordance with the provisions of the law of officials punishment and crimes against public security and interest in addition to compensation for the damage inflicted.

Article 51: The driver who is making use of the registration or license plate of others' vehicles or places his own vehicle's registration or license plate at the disposal of others is punished according to article 46 of this law and additionally in accordance in accordance with the provision of the punishment law of officials crimes against public security and interest. In case of changing or eliminating the machine number or the chassis number of a vehicle, the wrong doer in addition to the punishment included in the officials crimes against the improsonment or to equal fine punishment.

Article 52: 1. A person who obstructs the public road, without getting a príor police permit, for placing construction materials and obstructing the road or making the road impassable or narrow, will be imprisoned for one month or fined 2,000 afs. or both.

2. Vendors and travelling salesmen will be fined 5 to 10 afs. or punished through payment of fines if they obstruct the public road.

Article 53: The financial punishment which is fixed by the traffic police for the violators of traffic regulations will not exceed 500 afs.

Article 54: Violators of articles 5 to 18 of chapter 3 of this law in case they have not caused traffic accidents will be subjected to the payment of fines as follows: 1. Pedestrians who have reached the age of maturity, persons who drive animals or hand driven carts will be fined 2 afs. for each violation.

2. The driver of a motor driven vehicle who violates the provisions of this law will be fined $50 \mathrm{afs}$. for each violation, and if there are several violations, the traffic police is bound to collect cash.

3. Cyclists and animal driven cart drivers will be fined 5 to 10 afs. against each violation of the provisions of chapter 3 of this law.

Article 55. Violators of articles 19 to 28 of chapter 4 of the law will be subjected to payment of $100 \mathrm{afs}$. in the form of a fine, in case they are not subject to more punishment as provided by this law.

Article 56: Violators of the provisions of chapter 5 of this law will be materially punished as follows:

Violators of Article 29 of chapter 5 of this law will be subjected to the payment of 100 to 500 afs.; Violators of clause 1 in article 30 will be fined 50 pools for each kilogram of extra load; Violators of clause 2 in article 30 will be fined 50 afs. for extra passengers; Violators of clause 3 in article 30 will be fined 5 afs. for each afghani overcharged; Violators of clause 1 of article 31 will be fined one afghani for one centimeter over load put up on the roof with the height of 25 centimeters; For loads up to 50 centimeters, 2 afs. and for loads more than 5 centimeters, 5 afs. for each centimeter. 
Article 57: Violators of article 37 of chapter 7 of this law will be punished in the form of a 100 afs. fine. Violators of article 38 of chapter 7 of this law will be punished in accordance with the provisions of article 48 of this law. Violators of article 39 of chapter 7 of this law will be punished in accordance with the provisions of article 53 of this law. violators of article 40 of chapter 7 of this law will be punished in the form of a 100 to 500 afs. fine.

Article 58: The violator is obliged to compensate the damage caused to a person as a result of the violations of the traffic regulations included in this law.

Article 59: This law is enforced on the date it is published in the official gazette. With the enforcement of this law, the 1326 traffic regulations with their annexes and amendments are abrogated.

Graduated Land Tax Law

Chapter I

General Provisions

ARTICLE (1)

This law is legislated fo: thr purpose of regulating the tax affairs of agricultural land.

\section{ARTICIE (II)}

The following terms used in this law shall have the following meanings:

1-The Owner of the Jand is the pers'n who has complete legà authority on the land in accordance with a legal document.

2-The Payer is the person in whose name the land is registered in Main Registeration Book, Temp- orary Tax Book, or Declaration Bill and shall have the obligation to pay land tax according to the provisions of this law.

3 - Main Registeration Book is a book in which is registered the land ownership of the person on the basis of valici documents.

A - Tompomay Tax Bouk: is a book used for registering taxes lcvied on surplus lands and is not recognized as a basis for ownership.

5 - Natiral events: Are unexpected catastrophies such as earthquake, flood, drought, plant hazards and the like.
6-Tax Declaration of paper which shall be filled by the tax paper and certified by the certifiers for the purpose of determining and fixing the quantity and quality of each lot of land included in the land holding: of the tax payer.

7 - Certifiers: are two land neighbours Pulwan shareek), chief of the village or district deputy, property officer and technical employee of the Ministry of Agriculture and Irrigation.

8 - Land measureme$n t$ unit: is one jirceb whi$\mathrm{ch}$ is equivalent to 2000 sq. meters or one-fifth of a hectare.

The arca of land compu. ted on the basis of a jirect: equivalent to $1936 \mathrm{sq}$ metres shall be anended to the jirceb equivalent to $2000 \mathrm{sq}$. meters in accordance with (0.968) multiplier.

9 - The fiscal year shall be the 12 moriths of solar year which begins from the first of Hamal.

10 - Family: It consists of the head, as food provider, wife and children not reached the legal age and are under direct custody and guardianship of the head of the family.
In this family the head is recognized as the tax payer.

11-Plot: It is a land which constitutes the total or a part of the payer's land holdings and is bounded by neighbours,'s lands, river, public ditch. public road, mountain or state lands.

12 - Land holdings area: is one or several lots in nossestion of the tax payer. Land holdings arca can be in the forms of plots of land in one or sevcral tax zones

ARTICLE III

Land tax is a right which the state secures from the payer on the basis of the graduated tax system in accordance with the pr. ovision of this law.

\section{ARTICLE IV}

Each. plot of land holdings included in the Declaration Bill of the owner and payer is graded according to the contents of table No. (I). For this purpose all agricultural lands are divided into three categories and seven grades.

\section{ARTICLE V}

The ownership of owner's land holdings can be transfered, partially or totally, to another person, on the basis of oyder bearing documents, with due explanation as to the quantity and quality of the land registered in the Ma in Land and Tax Registcration Books after the owncr meets all his tax obligatiresuctic vi

The ownerstip of land taxed temporarily can ne. ver be transfered until the results of the land survey and Land Final $\mathrm{Cl}$ earance are obtained.

\section{ARTICE VII}

The payer and the owner shall have the obligation to fill the land Declaration Forms, annex III. distributed to him through the respective tax zone and declare his land holdings area in lots and complete them within the period declared by the Ministry of Finance and submit them to the respeective zone.

Chapter II

Specification and collection of tax

\section{ARTICLE VIII:}

The total area of land holdings of a tax payer is determined from the Declaration Bill and the Main Land and Tax Registerintion Bocos.

\section{ARTICLE IX}

For the purpose of determining and classifying graduated taxes the grade of each lot of the land holdings of the tax payer is amended to first gráde land on the basis of mul- 


\section{1 - First grade land \\ ARTICLE XV} 1.00 multiplier

2 - 2nd grade land 0.85 multiplies

3 - 3rd grade land 0.67 multiplier

4 - 4th grade land Q.40 multiplier

5 - 5th grade land 0.20 multiplies

6 - 6th grade Janr 0.15 multiplier

7 - 7 th grade land 0.10 multiplicr

\section{ARTIClE X}

With observation of the provision of Article $1 \mathrm{X}$ of this law in computation of graduated tax land with an area of more than ten Beswas (20 beswas is equal to one jireeb) is counted as one jirneb and land with an area of Jess than 10 Beswas is not counted at all.

\section{'AR'TJCLE X'}

Graduated tits on the total land holdings of the tax payer shall be computed and determined according to Table 2 of this law. The total land holdings are amended to first grade land in accordance with article IX of th law.

\section{ARTICLE XII}

In case the tax payer would have several lots of land in one or in several tax zones his taxes shall be computed and collected in the zone where he possess the largest lot among his land holdings. The payment of taxes levied on the payer is notified through the said zone to other tax zones where he may have one or several land holdings along with a copy of the Declaration Bill.

\section{ARTICLE XIII}

In case of the absence and death of tho owner or the payer the land tax shall be collected from the hiers or their legal advocate in the name of the payer or owner

ARTICLE XIV

Claims about the ownership or use of the land cannot postpone the payment of land tax. ce ninuer ine follows: forms
If the owmership of land is transfered from one person to another during the first or second quarter of the year the yearly tax on the ownership-transfered land shall be progressively computed and collected from the new owner. If the transfer of the ownership occurs during the third and fourth quarters of the year the yearly tax shall be collected from the former owner.

ARTICLE XVI

Land tax is paid once a year begining from first of Sunbula through the end of Dalw of the year. The payer may pay all or part of the tax in advan-

mrivitiges and exemptions

\section{ARTICJE XVII}

The owner and the payer who own or possese two jireebs or less than two jirecbs of first grade land or its equivalent aire cxempted from tax. Sinilarly, the owner or payer whose land holding is five jireebs or less than five jirecbs of first grade land or its equivalent shall enjoy this privjlege. The area of land holdings and the tax exemptions for the graded land are determined as

Grade area of landings bringing it under cultiva-
Ist 5 jireebs \& less tion shall be exempted
than that from tax for the first
2nd 6 jireebs and - three vears.
less than that Tax-exempted land
3rd Beswas and less than 2 jireebs.
4th 5 jireebs and

10 Beswas \& less than that

5 th 25 jireebs anc Jess than that

6 th 33 jireets anc 10 Beswas \& Jess that

7 th $\quad 50$ jireebs ane less than that

But the owner and th payer who enjoys the pri vilege of this article sha] be obliged to fill the Dec laration Bill and other 31
ARTICLE XVIII

State owned lands, public Trust lands and municipal lands are exempted from tax. The complete data on these lands together with destription of their areas, quality, and boundaries shall be included in the declaration form, prepared and filled by the respective offices and shall be submitted to and registered by tax departments.

\section{ARTICLE XIX}

With due consideration to the provisions of Article XVII of this law, 20 per cent tax reduction shall be given to a member of aglicultural cooperatives whose land holdings do not exceed ecjuivalent of five jirecbs of first glade land Similarly, 10 per-

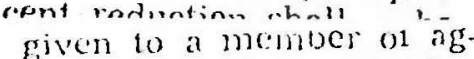
se land holdings do not execerd cquivalent of $\mathrm{je}$ jireces of first grade land. The reduction will be abrogated if and when the membere leaves the cooperative.

\section{ARTICLE XX}

The land distributed. according to the provisions of this law, under the land reform and settlement program and, likewise, barren state land sold with the object of bringing it under cultivation shall be exempted from tax for the first Tax-exempted land

3 jircebs

5 jireebs

\section{0 jireebs}

13 jireebs \& 10 Beswas

20 jirecbs riculuwal cooperative who

\section{AR'TICLE XXI}

The owner of an agricuItural land which is damaged as a result of natural catastrophies shall be exemuted from tax until it recuvers and beçomes fil for cultivation.

The authority to determine the rehabilitation period for a damaged land within three years is vested with the administrative meeting of the province concerned and the $\mathrm{Mi}$ nistry of Finance. And if this period is proven not enough for the rehabilitation of the Jand it may be cach month delayed during the first tax year.

b. Two per cont for each month delayed during the second tax yeai.

2 - If the owner and the payer do not pay thejs taxes until the end of the third tax year the corps of their linds shall bo put under the fovernment watch and control upon the proposal of the provinrial fovernment and the.

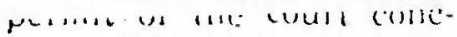
erued. Whan the crops ripen and are harvested the violds shall be culd b: a delegation alpointed by the province concerned. And out of the cales proreeds the tax and the fines shall be collected.

3 - In computing fines 15 days and more are counted as one month and less than 15 days cannot be counted.

\section{AR'TICLE XXIV}

If the cause of delay in computation and collecti(1n of tax is directed towards responsible officials they shall be prosecuted according to the provisions of law.

\section{ARTICLE XXY}

In case the owner or the payer declares the areas of his land holdings less with an attempt to reduce the amount of tax and/or provides untrue information in a bid to lower down the grade of the land and if this act results in reducing the amount of tax 15 per cent he shall be 
prosecuted to pay an annual fine equal to double of the amount of tax reduced in each year. If the reduction raches 15 percent or more the owne: and payer shall be prosecuted to pay yearly fine equal to three times of the amount of tax evaded. Chapter $r$

Miscelleneous provistons

\section{ARTICLE $X X V I$}

If land owners, including those who may make use of the tax exemption privilige of this law, are indebted as a result of not paying land tax and its fines prior to the enforcement of this las they shall be bound to pay their debts unti) the end of the extended upon the proposa) of the prorincial admnistrative mocting and agrecment of the Ministry of Finance.

\section{AlY'ICLE XXI}

If the output of the land is totally or partially damaged as a result of r:atural catastrophies the tax of that rear shall be either reduced in proportion (1) the dimnage recejved of cxompted alter advanc-

upon approval of the provincial administrative mecting and sunction of the Ministy of gemance.

Chaples iv

Penal provisions

ARIICI,E XXIII

1 - If the owner or the payer does not pay his land tax until the end of the month of Delv of the tax year he shall have the obligation to pay the following fines in addition to the tax levied:

a. One per cent for month of Delv 1355. Otherwise, they shall be subject to cash penalty inder this law.

ARTICLE XXVII

The payer is bound to inforn the tax authorities concerned of the change made in the grading of his land with the object of taking the following measures:
1 - If the glade of land falls down the tax on the newly graded in which the change is made in the grading until it is corrected.

2 - If the grade of land rises up the tax on the newly sraded land shall be collected fiom the payer beginning from the fourth year of the change made. Failure to notify the tax officials of the change to a higher grade shall be subject to fine specified in Article $\mathrm{XXV}$.

3 - Approval of the change to a new grade is of the authority of the provincial administrative. mecting.

\section{ARTICLE XXVIII}

In case the mombers of a family separately own land, lax shall be progrestively calculated on the total land holdings of the famiy members and collected from them accordingly.

\section{ARTICJE XXIX}

The Ministry of Finance is bound to prepare and enforce land tax regulations according to the provisions of this law.

ARTICLE XXX

With the emforcement of this law other laws and regulations that are contrary fo the provisions of this law shall be comsidered ahrarrater?

ARTICIE YXXi

This law snal be in for. ce after it is published in the Official ciazette.

$$
\text { ( }: \therefore \text { d) }
$$

$* * * * * * * * * * *$

NEW LAND REFORM LAW OF

$$
\text { AFGHAN ISTAN }
$$

APTER I

iCl.E I:

Ihe folluwing terms used in this baw shall have foltowing meanings:

1: Farmer:

Farmer is the person whose actual occupation is agriculture and in having one or more agricultural production means either personally or with the cooperation of the members of his family and direclly qultivates some agricultural land which he does not own. The yicld from the land is shared by him and the proprictor of the land in accordance with previous legal agreement.

2. Agricultural Labourer:

Asricultural Labourer is the person who is not the proprielor of the land and toils on the soil or other specific duties on the land of the landlord in accordance with previous Jegal agsement or local tradi. tion against cash wage or in kind.

\section{J.oprictor:}

Proprictor is the person who, in accordance with authentic legal documents is in possession of his property.

4. Distributable land:

)istributable land for purposes of land reforms consist of:

\section{a. State land.}

b. State land acquisitioned illegally by indiviciuals.

c. Land acquisitioned in accordance with the provisions of this law.

\section{Land :}

l.and is the arca which is under existing agricultural exploitation.

6 land holding:

Land holding is one or nore plots of land which are recognised as privale property in accordance withe legal authemlicated docunients

7. Chief of family:

Chief of family is the person who is responsible for providing livelihood for members of his family.

\section{Family:}

Chief of family, his wife and ummarried children who are under direct warelenship of the chicf of the family are considered as one person for the purpose of this law.

\section{Collective Farm:}

Colicctive Farm is the land distributed to descrving persons in a specific agricultural unit on collective basis.
10: Council:

The supreme land orms council.

11: Office:

The land reforms admi. nistration within the framerrork of the Finance Mi. nistry.

12. Cooperative:

Asilicultural coopcratives

CHAPTER II

Agricultural Land in ${ }_{3}$ Ceiling;

APTTCLE J :

1. No one is permitted to have land holding beyond the following reilings:

a. Two crops, irrigated land holding of one hundred jeribs, (twenty hecta es).

b. Orchards holding one hundred jeribs $(20$ he ctares)

c. One crop, irrigated land holding of 150 jeribs or thirty hectares.

d. Dry-farming land hol. ding of 200 jeribs (forty hecetares).

2. If the land-holding of a person...consists of lwo or more varietics of land holdings as mentioned in the above articic, the ceil ing for private proprictor ship of the person shall be regulated in accordance with separale statutes.

ARTICLE IJI:

1. Companies and private agricultural societies can. in accordance with the ag rcement of the Council. have holding beyond the cciling referred to in Arti cle If of this law on the condition that the surplus is arid land and they malec it cultivable.

The above inentioned ow nors will be dealt with, in accordance with article $X$ of this law, after passage of fiftecn years.

2. an individual can own land more than the ceiling set under Article II of this law through inheritance. The individual is obliged to transfer the surplus land to somebody else within one year or else the surplus land will be acquisition cd by the state. 
ARTICLE IV:

The surplus land beyond the ceiling set by Article I) of this law shall be expropriated in accordance with the previously written notification. The propriefor can utilise the yield till the cnd of the scasoin.

\section{ARTICLE V :}

The price of trees, buildings and other paraphernalia belonging to the land exprepriated in accordance with this law shall be paid fo the owner aiter the doduction of consumption cost pursuant to specific regulations.

\section{ARTICLE VI:}

After the enforcement of this law, the state shall incessantly resort to acquisition of the surplus land in accordance with artinle II of this law. Acquisition shall start from largest agricultural holdings.

\section{ARTICLE VII:}

From the the date of the cuforcoment of this laiv. the surplus land not covered by proprictorship documents shall be considered as state property.

\section{ARTICI,E VIII:}

Should cxccution of statc development projects require, the Counci! can exchange the land holding under the land reforms bill with another land having the sume area.

\section{Aliticis ix:}

In case the acquasitioned land and equipment betonging to it are moder sccurity, from rompensation moncy under Article to of this law first dues of the person/persons shall be paid. The remaining money shall be paid to the owner of the land.

\section{ARTICLF $X:$}

Acquisitioning of land by the government for purpose of land reforms shall take place in accordance with compensation. The price of the acquisition? jand shall be regulated by the regulations of the price pavment.

The government shall pav for the acquisitioned land in 25 years in accordance with the acquisitioned document along with 2 per cent interest.

\section{CHAPTER III}

\section{ARTICLE XI :}

The lands distributable in accordance with the provisions of this law, shall be distributed in accordance with separate regulations and with due consideration to the conditions of the area, varicty of land, livesihood of the family" and putting to work its members and other criteria.

ARTICLE XII:

The person eligible for land distribution shall have following qualifications:

1. Shall be an Afghan national and shonld have reached lowal age.

2 Shall be landless

\section{ARTICLE XIIT:}

The following persons have priority in land distribution:

1. The farmer, who, prior to the promulgation of this law has been toiling in agricultural work on distributable land.

2. Landless nomads.

3. Farmers and land labourers.

4. Ciraduates of agricultural and cattle raising schools.

$\therefore$

\section{ARTICl, XIV:}

Jistribution of land shall be executed in different parts of the country in acccordance with the prepared plan.

\section{AIRTICLE XV :}

Distribution of Jand shall continue incessantly from the time of its acquisition.

\section{ARTICLE XVI:}

Pending the payment of all installments of their dues incurred from the receipt of land, the new own- ers will be given temporary ownership decuinents by the statc.

\section{ARTICLE XVII:}

The Council can temporarily' stop, when need be, the acpuisition of land.

\section{ARTICLE XVIII:}

The person who receives distributable land is required to fulfill the following cbligations:

i. The person shall take possession of his and land within four months from the date of distribution advertisement. Otherwise, without the existence of reasonalble excuse, his right shall be forfeited and his land shall be given to others who meet the conditians of clistribution in accandance with this lak.

2 The chich of family and merrbers of his family are dutybound to directly rxploit the land: otherwise the land shall be acquisitioned from him and dis. fubuted to other deserving jersons

3. Lind holding given to wroons as a unit of prod. sation must conlinue to contain its entity and they me oblieced to keep it as ach without dividing it inlo units.

4. The person who receis. land can not have offiial job, otherwise the land will be taken from him.

\section{AJTJCIE XIX:}

1 Should the chice of the family die. his desecnditits are recpuired to prese ave lice unity of the landholdines without dividing it into units, and should distribute the yield among themselves.

2. If the dexcentants can not exploit the land. they may, with due respect in the provisions of this Jav sell it to another person. in accordance with regulations. In this case the pay. ment of the remaining instaments shall be on the new buyer.

\section{ARTICLE XX:}

When the chief of the family dies. his descend. ants are obliged to inform the concerned land reforms office about it. In case none of the descendants is found eligible, the office is dutybound to take necessan measures, within the bo:lnds of the laws and regulations for continuation of the exploitation of the descendants land

\section{ARTICLE XXI :}

Percons who receive bim in accordance with the pre. visions of this lall can form cooperative socictios

\section{ARTICLE XXII:}

The proprictor who has received land in accordat cr with the provisions this law is cintitled to pa. 3 per cent interest annual. ly towards administrative cost on total of installm. cuts due for payment in ad. dition to payment of not mal installmeint.

\section{CHAP'IER IV}

\section{AlTSICLE XXIII:}

To prepare a general pro gramme, compile necess ary regulations and stalut cs and supervise ajplicat: on of responsibilities cn visaged in this law, and to implement the oljectives of the land reforms, a counci shall be established under the chairmanships of the Prime Minister whose me mbers are comprised of:

1. Depuly I'time $\mathrm{Minis}$ ters,

2. Justice Minister.

3. Finance Minister.

4. Plaming Minister.

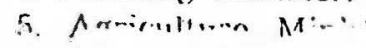

\section{A!TICLE XXIV:}

Tlye Commoi mocis al ie ast ance a monily.

AlTiCle $x \times V^{\prime}$

The cluties of the Coun (i) const of:

J. Dovising and pinpoint ines he raidelimes and po licy of the inplementation of the land reforms in ac corclance with the prov isions of this law.

? Pronosing rcgula'in-. statutes and bylaws related 


\section{ARTJCIE XXVII:}

to land roforms within the provisions of this law to the cabinet.

3. Approving and fixing the price of the acyuisitioned land and the price of distributable land.

4. Deciding on gencral issues inclurling financial matters related to the of fice.

\section{ARTICLE XXVI:}

The proposal for the establishment of Office (ref. orms office within the framework of the Finance Ministry) shall be nate b: the Council and approved by the cabmet.

The dutics of the office arc:

1. Implementation of lands arquisition in accordance with the provisions of this law.

2. Distribution of Jands in accordance with the provisions of this law.

3. Madulaning liaison will concerned anthorities for the implementation of the provisions of this law.

4. Drafting regulations and statules and proposing then to the Council.

5. Preparing the anmual hudget and gielling the cndorsement of the concerned higher authorilies in accordance with the Budget and Accounting I,aw.

6. Fecuting the instruclions and orders of the $\mathrm{Co}_{\text {- }}$ uncil.

7. Fixing the prices of moveable and jumbuable agricultural establichments and cquipneni and proposing the sane to the Couicil.

8. Finding exceptional cases and proposing then to Hlie Council.

Q. Fixing and clearing the surplus state lands acqui-

10. Preacuting 1h. rep.

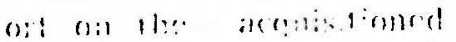
and ris!ribul(c) bands in the Cimncil.

1). Other oblimations, duli:s and allhorities which the Council entrutsis to it.

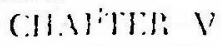

To alleviate differences cmanating from application of land reforms, the slate chall establich a Special high Court on land reforns.

\section{ARTICIE XXVIII :}

Decicion made by this court is find and irrevocabic: The court also has the authority to issue jts decicion, dismiss cases or give? clearance.

\section{AITICLE XXIX:}

If during the handling of a case the Inwer spccialic. ed courts and overlootied the consideration of authentic doroments on which the decision should have been based, or if the decision of the specialised cowt is repugnant with the law of to utter loss to the person of the state. the case shall be handled by the Snccial High Court.

\section{AM'TICLE $X X X$ :}

To seltle property claims cmanating from clcarance or acyuisitions the state shall establish permanent or mobile specialised couris.

\section{ARTICLE XXXI:}

The specialised courts sliall attend to solving disputes originating from land acouisition. No claim or complain shall be emertained thirty day's after oflicial drcision on land acquisition has been pronounecd.

No court has the light to interfore in dispules arisin ${ }_{i s}$ from land relationship. Such clispules are referred to by the orfice to the specialised land reforms conrt.

AlllfLi: $\mathrm{X} \times \mathrm{X})$ :

A:sicullural cosperatives shall be formed in accord. ance with the Cooperatives Liay which was promulnaled muler Decree No. 861, dated Agrab Nine, Afghan year 1353:
Al'i']CLE XXX'II :

Allocations and credits necded for the implementation of this law and alloiments required by the office and for land reforms operation shall be made as part of the general budret of the country and shall be put at the disposal of the Orfice.

\section{AJTICLE XXXIV:}

Ducuments on ownersmo of distributed lands shall be deposited with the Agriculture Development Bank of Afghanistan. The Bank, on bchalf of the state, is duty-bound to collect the anmual installments ciue for payment by individuals from the price of the land

From the funds thus collecled, and when it is not adcquate, with the financial ascislance of the state the volume for which shall be estimated and included in the general budget of the country, the yearly installments to the previous own(rs shall be paid;

\section{ARTICLE XXXV:}

The Agriculture Development Jank is duty-bound to study the credit needs of the deserving persons who may recejve la. nds in areas where, in accordance with the provis ions of this law, land distribution is undertaken, prior to distribution and to clevise special, cffective and possible programme for each area and to carry it out after felting the cndorsement of the Council

\section{CHAPTER VII:}

- Miscellancous Provisions

\section{ARTCl. $X X X V 1$ :}

Hor acyuallon of the surplus ceiling land shall be undertaken when a priof official notification is issuad by the Conncil in the area muder comsideration. lending the acquisition of the surplus ceiling land re. ferred in in Article 11 , the proprietors shall contimue to exploit it

\section{AR'TICLE XXX'VII}

A person who receive land can not lransfer its propriertorship or mortg. age it till he ays all the installments of the price of land and fullills all other obligations thercof.

\section{ARTICLE XXXVIII:}

Sale and purchase of land sliall lake place in accore. ance with regulations vised by the Council.

\section{AlTTICLE XXXIX:}

When a person who has reccived land does not pay threc annual installments consccutively without reaconible excuse and ignorcs official notifications repard to payment of in: tallments thercof, the land shall be recguisitioned the state and shall be given to another person in accordance with the provisions of this law.

\section{ARTICLE $X X X X$ :}

All administrative proc edures related to trans? of lands under the provis. ions of this law, one party of which is the state, are undertaken without any tap. or tolls

ART'ICLF, XXXXI:

The land revenue on lan. distributed shall be exae: ed from the new owner accoldance with the Land Revenues Act from the da ic of handing over

ARTICLE XXXX'II:

When, without reasona ble excuse, a person lea ves his land and does no cullivate it within sid ric nths, the land will be reo quisitioned from him zu: given 10 descrving peison in accordance with the pro visions of this law.

AITJCLE $\therefore$ XXXII:

The Council. in accordan* with the provisions of us latw shall devise regutions and statules and afr legislation shall enforce (in).

\section{ARTICIE XXXXIV:}

This law is entorceably c year after publication the Official Gazette. 


\section{Chapter One \\ General Provisions}

ARTICLE 1.

1. This law has been passed in order to regulate the production, importation and distribution of generic drugs.

\section{ARTICLE 2.}

2. The following words have the following meaning in this law:

a. Generic Drugs: Drugs produced under their ofticial and scientific names.

b. Drug: $\triangle$ ny substance or mixture of substances made available to those who need them for the treatment, prevention and diagnosis of diseases or alteration, and correction of the functions of organs in human or animals.

c. Production: Processes used in the preparation of drugs including synthesis, compounding, formulation, packing and labelling.

d. Raw Materials: All the active and inactive substances used in the various stages of production as a result of which the stubstance is either changed or ren:ains unchanfed.

c Batch: A quantity of drug prepared under sinuil. ar and regular processes which has uniform propertjes.

f. Batch Number: A unique symbol written on the label of a batch reference - to which will make available the document for all the stages of the production and control of that batch.

g. Whole-saler: Persons who have trade license and have completed the conditions for obtaining the right to import drugs.

\section{Chapter two}

Consumption and use of Generic Drugs

\section{ARTICLE 3.}

All the sovernment health irstitutions have :s mencha. se the drugs and medicai

raw matenials which they need from Avicmona Pharmaceutical Institute.

\section{G E N E R I C D R U G S I A W Purziched Official Gazette, $11 / 76$ \\ Enforced, May, 1977}

\section{AR'TICLE 4}

All the government health institutions such as the hospitals and health center's of The Ministry of Public Health, hospitals of the ministries of Defence and Police, Education, Public Works, Mines and Industries, and goverimental health jnsurances have to use only gieneric drugs.

ARTICLE 5.

No physician may prescr. ibe patent drugs for the governmental hosjitals and polyclinic patients.

\section{ARTICLE 6.}

Palent drugs whose generic equivalent may not be availabie are exceplion to the Articles 4 and 5 .

ARTICLE 7.

Any patent drug whose generic equivalent may be obtained cannot be newly registered in The Afghan National Formulary.

\section{Chapter three}

Inportation and Production of Generic Drugs

\section{ARTICLE \&}

The generic drugs needed in the governmental institutions are inmorted or prod. uced by The Avicems Pharmaceutical Institut?

\section{ARTICLE 9.}

The whole-salers nave to import the whole amount of generic drugs delermined and assigned to ihen by the Ministry of Public Hea)th.

\section{ARTICLE 10}

The generic druss can 1 purchased only from companies who have fulfilled the following requirements:

a. Presentation of document proving the use of the drug produced in the country of origin.

b. Presentation of production license from the re lated health authorities for the drug in question.

c. Presentation of quality control documents for llic juoduced drug from a conl-est and will not be added inl labolatory of the count- to the price of the drug. $\therefore$ of origin. d. Presentation of cxporting license for the produ. ced diug: to other countries.

\section{ARTYCLE 11}

Drugs which do not have the following information in their label cammot be sold in the market:

a. The generic name of the drug

b. The quantities of active ingredients.

c. The standard of production:

d. The name of producing company.

e. Batch number.

f. Expiration date if any. ARTICLE 12.

The whole-salers have to obtain . Proforma invoices from three or more cumpanies who have fulfilled the requirement of Articie 10 and present them to lhe Avicenna Pharmaceulical Institute in order to get import permit.

The Avicenna rnarmacentical Institute can give permit only from the company whose offer has the least jrice and optimum condition of delivery.

\section{ARTICIE 14}

The wholp-salers cannot obtain pernit of importation of patent drugs before the import of all the generic drugs whose perinit of importation they had obtained previously.

\section{ARTICIE 15.}

If a whole-saler cannot obtain proforma suvoice from three or more companies who have fulfilled the requirements of Article 10, The Avicema Pharmaceutical Institute may procure ihe required proforma juvo. ices for him provided the whole-saler will pay onc percent of the price of the ding to The Avicema Pharmaceutical Institute. The whole-saler will pay this money from his own inter35

\section{ARTICLE 13.}

ARTICLE 16.

The publication of $A$ ghtan National Formulary will be renewed every two years. In the years 3978 and 1980 a list of generic drus will be included in it whose patcint forms canno: be produced or imporicd.

\section{AR'TICLE 17}

locally producing ins tions whose patent prodh, are included in the problib ted list of Article 16 of this law, may produce and distribute their products umier gencric names. Produciion for export purpuses is jan exception to this Article.

\section{ARTICLE 18.}

In the Afghan National Formulary in the year 3982 only generic drug will be published.

\section{ARTICLE 19}

Drugs whose form will not be available are exception to th Article 18 which will be imported only by The Avicenna Pharmaceurican Institutr

\section{ARTICLE 20.}

Any patent drug not registered in The Afghan Naticonal Formulary whose presence by The Minster of Public Health will be considered vital and necessary can be imported by the Avicenna Pharmaceutical Institute.

\section{ARTICLE 21.}

Drugs coming by way of donation and aid not registered in The Afghan Na. tional Formulary can loe distributed with the permission of The Minister of Public Health.

\section{ARTICLE 22.}

Drug arriving for the research purposes at the scientific institutes or reavested by research institutes can be permitted with the approval of 'Th: Minister of Fublic Health.

\section{CHAPTER FOUR}

"PUIBLICITY ACTS"

\section{ARTICLE 23}

Schools of Medicines, Pharmacies, Veterinaries and other medjcal teaching institutions have to teach drugs under their generic names. 


\section{ARTICLE 24.}

Every type of commercial publicities of patent cirugs are prohibited.

\section{ARTICLE 25:}

No physician mat mention the names of producing companies in their prescriplions.

\section{IRTICLE 26.}

$\Lambda$. Palent drug cannot be :lited in the vitrines of gofernmental healti institulions for purpose of pubiirity.

33. If placed in order to compare patent drugs with sencric ones it is permitted. CIAPTER FIVE

IUNITORY ACTS

\section{ARTICLE 27.}

If any person without the permit of The Ministry of Public Ilralth import any drug on case the drug is registered in The Alghan $\mathrm{Na}$ lional formulary if will be confiscated, otherwise over and above the contiscalion wi the drug the person will be condemined by a fine of lires times the price of Here drugs.

\section{ARTICLE 28.}

Iny imported getweric det1: which do sot conform $\therefore$ ill the specifications giv' $n$ in Article 11 of this law will be confiscatted.

AITICLE 29.

Violators of Articles $\vec{u}$, 1 aind 13 of this la:y will be conctemned accorting to the accepted laws of The Repuhic of Afghanistan.

AITTICIJE 30.

Whole-silers of Allich ? ; Hhis law who fail to jim. port all of the generic drugs anjuned to them withiu wile year from the date of is sigrment of the drugs: sill condenued by loss of his license as a whole-salcr. IRTICLE 31.

Violators of Article 37 of lins law will be courlenned by loss of his liccnse as a vioducer of drugs.

ARTICLE 32.

Violators of Articles 5 . 25. 33 and 34 of this law will be fined 500 Afghanis. Miscellaneous $\wedge \mathrm{cls}$
ARTICLE 3:3.

No physician may write a prescription for a pationt arimitted to a goverimmential hospital for a drug available free of charsi is al! allients ju order to be pur-hased from the i mirkel and brought to jhe hosyital.

\section{CIIAITIR SIS.}

\section{ARTICLE 34.}

No plissician may merseribo diugs not regislered in The Afghan Nationil Form willy.

\section{ARTICLE 35.}

rhis law will come into force six months after the dale of jts publicalion in 'The Offinal Gametle. NOTE:

Note: The rasintu Dari texts are valid.

$* * *: * * * \div \div * \neq * * *$

NORMS AND STANDARDS CHARTER (KT, 4/24/25/77).

\section{1!APTER ONE}

12LE AND PURTOSE

This Charter has been nforced before March 1977 (Hoot 1355) ).

AliliCLE 1 :

On the basis of Cabinet resolution and endorsement of President of the Republic of Afghanistan and according to Decree No. $32617 / 8 / 1352$ of Pri. me Ministry, a Department of Norm and Standard has becn established in the Ministry of Mines and Industries.

ARTICIE 2:

The main purpose of Norms and Standard Departm. ent is the strengthening of National Economy and protection of consumers and producers as following:

1-Defining of National standards and desired quality and conomy of domestic products and their clevation on the basis of national and international requirements.

2-Defining desired quality and minimum of standard for inported goods.

3-Maximum and rational use of productive re- sources and economising the use of material and human resources.

\section{CHAPTER 2 TLRMS}

ARTICLE 3 :

Terms used in this Char. te: have the following meanings:

1-Standardisation:

Standardise products on the basis of defined samples. -

\section{2-Standard :}

Result and output of defincd labour of standardisation.

\section{3-Norm:}

Definition and recognition of concepts, variety and scales, figures, colors, patent, measures samples and subscriptions on the basis of average quality and quantity by related authorities.

4--Technical specifications :

Specifications means envisaged criterion of products:

\section{5 - Products or outputs. \\ Products or outputs are}

combination of in-puts whicb are the result of production process according to a defined plan and satisfies a specific need.

6-Quality :

Quality is the combined spccifications of produce. which on the basis of use and usefulness is cnvisaged and satisfies a specific need.

7 -International standard. International slandard is the standard that prepared by member countries and international standard institutions and accepted by the institution.

8-International standard institutes:

International standard institutes are the institutes which national standard institutes of countries for the purpose of standardisation cooperate with cach other.

9-Regional standard institutes :

Are the institutes which include members from the preparation and implementation of standards for theit mutual benefit.

10-Recommendation note of international standard in. stitutes:

Reconmendation note of international standard ins. titutions are the documents prepared on the basis of conomic studies and resear ch and are distributed to those interested to implem ent.

11-Sign of quality:

Sign of quality is a sign of Norms and Standard De partment which the privile ge of its use is given fo: a specified period to speci fied domestic products af ter the evaluation of their p-roduction methods.

CHAPTER 3

RESPONSIBILITIES

\section{ARTICLE 4:}

Norms and Standard De partment will carry the following responsibilities in Kabul and other provinces, with cooperation of other institutes and ministries:

1-Preparing and defining national standards for all goods and products both

domestic and imported goods.

2-Defining methods evaluation and control national standards.

tions.

3-Study and research of international standards and their use and adoption domestic conditions.

4-Publishing of approwed standards and their im plementation to their res. pecled fields.

5-Cooperation with scientific, industrial and trade institutions, (private and public sector) and study of their proposals for prepar. ing drafts of standards of institutions and standards of traditional handicrafts.

6-Carrying different tcchnical and economic resea$\mathrm{rch}$ and studies for the purpose of preparing national standards, through organis. ing activities and coopera tion of related departm. ents and institutions. 
7-Cooperation with in. ternational regional and national standard institutions and use of their experience and recommenclations:

8-Attraction of cooperation from universities and scientific and educational institutes' of the country for the purpose of evalua. tion of standards and quality of products.

9-Preparing regulations of the Department.

10-Publishing and distvibution of publications related to standards.

11-Establishment of national and international standard archive for increasing use of standards.

12- Establishment and use of fixed and mobile laboratories for carrying scientific and technical research related to standard and quality of goods.

13--Training of technical and administrative personnel for development of different branches of standard, through conducting long and short term courses, seminars, conferences

and sending persomel to friendly countries to elevate their education and to. chnical level.

14- Scientific and technical guidance to trading and producing institutes fo: creating better conditions and facilities in order $t o \mathrm{im}$ prove quality of domestic products and reduce Jow quality imports.

15 - Examination and control of products and granting quality sign accos. ding to regulations.

16-Supervision, sampling and control of products on the basis of specified standards.

\section{ARTICLE 5:}

Norms and Standard Department is composed of the following organisations:

1-Suprense Commitlee of Norms of Standard.

2-Board of professional advisers.

3-Scientific, technical and economic committces.
4-Agencies which will be established in the Ministries, scientific and industrial institutions in the capital and provinces as required. ARTICLE 6:

Supreme Committee of Norms and standard under. the chairmanship of Minister of Mines and Industries is composed of the follow. ing nembers:

1-Depuly Minister of Planning.

2-Deputy Minister of

Agriculture.

3-Deputy Minister of

Public Irealth.

4-Deputy Minister of

Commerce.

5-Deputy Minister of

Education.

6-Deputy Minister of

Public Works.

7-Deputy Minister of

Water and Power.

8-Rector of Kabul Un:versity.

9-President of Department of Industry, Ministry of Mines and Industries.

10-Head of Norms and Standard Department as Secretary of the Committee.

\section{AR'TICIE 7 :}

Decisions of the Supreme Committes will be carricd on the basis of majority rule, provided that members present are not less than two third of the total mem. bers.

\section{ARTICLE 8:}

Meetings of the Supreme Committee of Norms and Standard are held on the basis of proposal from the head of the Department and approval of the Chairman of the Committee as required.

In case of need extra-ordinary mectings will be held on the request of Committee's Chaireman.

ARTICLE 9:

Supreme Committce of Norms and Standard has the following responsibilities and authorities:

1-Scrutiny and approval of proposed standards for getting the Cabinel ap proval.
2-Study of changes

the prepared standards.

3-Defining policies and taking measures to expand Norms and Standard to the national level and defining extension programmes of the Norms and Standard Department.

4-Study and approval of proposed privilege of quality sign.

ARTICLE 10:

Advisery lioard of professionals is responsible for giving expert view on programmes and activities and specialised subjects of the norms and standard.

ARTICLE 11:

Member of professional board consist, engineers, professionals of the Norms and Standard Deparlment and professional high ranking representatives of other government departments and industrial insti. tutes which are assigned by the Minister of Mines and Industries based on $\mathrm{pr}$ oposal of the Head of Nor$m s$ and Standard Department and approval of related departments and institutes. ARTICLE 12:

Scientific, technical and ecomonic commitlees for preparing and defining norms and standard will be established as required.

These committces have the responsibjlity to carry scientific and economic studies in the centre and provinces according to the prepared programmes of Norms and Standard Department. ARTICLE 13:

Members of scientific, technical and economic rommittecs, include specialists and engineers, of Norms and Standard Department and professional represen. tatives from scientific and industrial institutes and producing and construction and trade organisations, which on the basis of Norms and Standard Department reqnest will be assigned by their related organisation and selected by the Norms and Standard Department's head.
STANIDARDS AND TECHN

ICAI, SPECIFICATIONS

AR'TICLE 14:

All standards which ar accepted by noms and standard high commutrees and approved by the Coun ci) of Ministers are recogni scd as national standards.

AR'TICLE 15:

Decisions regarding the compulsory or voluntary implementation of stand. ards will be taken based o Norms and Standard Dep artment's proposal and app roval of the Cabinet.

ARTICLE 16:

Publishing and distribu tion of national norms and standards is the responsibility of Central Norms and Standard Department. CHAPTER 5

MUTUAL COOPERATION AITICLE 17:

In addition to the cstab. lishment of product's testing laboratories by Norms and Standard Department on the basis of bilateral co. ntacts and mulual cooperation the Department can use laboratories of scientific and industrial government institutes and companies.

\section{Arlucle 18}

Department of Norms and Standard can use the cooperation of scholars, experts and engincers in the sciontific, technical, economic and law committees. ARTICLE 19:

Department of Norms and Standard on the basis of individual agrecments and contracts can pay fees to scholars, experts and engineers for carrying out scientific, technical and econo. mic rescarchers.

ARTICLE 20:

Branches of Norms and Standards Department and quality control departments of other scientific and in. dustrial institutes are obli ged to follow procedures of the Norms and Standaid Department. 


\section{CHAP'TER 6: MISCELLANEOUS \\ ARTIC.LE 2 :}

In addition to the government budget the Department of Norms and Standard will be financed from the following sources:

1-Aid from international institutions.

2-Aid from standard institules and scientific institutes of friendly countries.

3-Aid and membership fee from related scientific, industrial and trading institutes,

\section{AlTTICLE 22,}

Following are the income sources of Norms and Standard Department :

1-Salc of publications and standards.

2-Fees against quality control and testing of products according to regulation.

3-Charges against gra:i. ting quality sign for domestic products, produced according to national standards.

4-Government Departments other than profitable enterprises are cxempted from fees.

\section{ARTICLE 23:}

Producing and construction factories and commercial and other institutes violating national and international accepted norms and standards in the country, and consequently damage the national economy. public health and national prestige will be punished according to the provisions of criminal law.

ARTICLE 24:

In all other cases not mentioned in this charter the Department of Norms and Standard is obliged to follow laws and government regulations. ol W.IA will. Within as

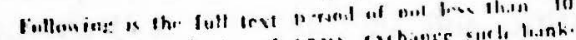

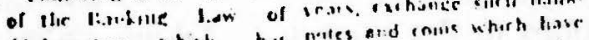

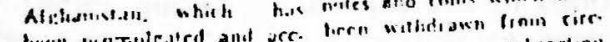

Wxin ? Alit of Articie 3 of llis l.w.

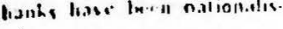
ad. MIONEY A1:Jic 1.1:1

1) Affanistan's mone lary unit is Alshani= pools.

2) Our Mfilioni is remis. airnt to vocisiasz from

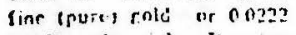
S.D.l. Bsocial Drawing Firlit.

3) The ciange in the

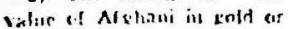
SIIt: was is miste on the

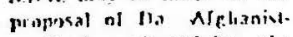

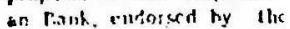
Mlinivire of Iillowice and opjorasl of tlie Council of Aluisti:t 5

a) The butin: and solling

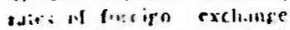

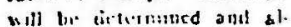
(1.2... 1.6 D) 1 B

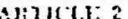

1) Currency vill be put in cirrutlation in the form al batkrnitrs and metal co. in:

2: Cuity bunknotrs ans nerial revins in cirrulalisin a! vlir time ol enforcemenat of this time or cuerents

whict witl be put in cuctul.

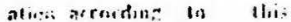
bav, are texal icnters.

3) l'marid of ill ditis and trancortinus are maje bx me.m. of cutcing in

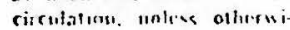

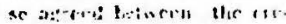

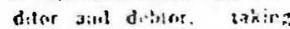

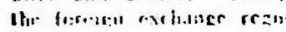

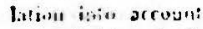

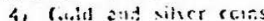

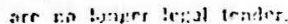

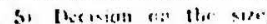

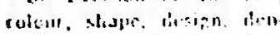

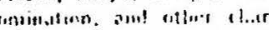
arterisics of lianhitate will Ix luter" on the rine

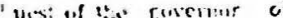

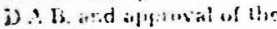
Ministr of Viristre.

(b) The flontinutes beje Vir sirnailures of the Mire iver of fintolye and the Covesnor of tha Alchanist. un liank.

7) II, b. with the urit

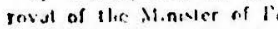
nonce, decicis on the quanlity and irmoninatiun of crise lestikin: in circu. b.time

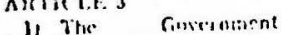

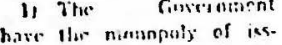
viale neciney, the sullinrity In inder menites lias bern solely dirlerejted is per liis law to ba Afgharistan nank.

21. The ceirut as reute. mptine of crills and lonh. notes. as wett as the means of funtlisise them nedt of rir. cutation ie deresnimed by B.A H., and will be publirly

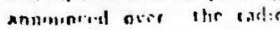
notel in the sofferial neweflit peres after it lies biren sobs imal lis lar lefinives of linaner.

\section{A!: : ICI.I: 1}

a) D. Atghonikt Jn Bunt

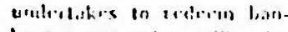
hiroles attid enins, will bic aceordine to the currens presents in use in the cuaniry

(b) IIA n aveme no re. promelelise in o.er of thre

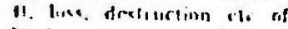

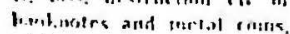
while hriel the the pathlis.

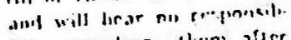
bies ersardace llims strer a.1.,

al The rquivalent of the anine will ber condiles is the aresunt of ther Minist. is if Finaner

inTucle: 5

a) 1) 18 . mon hast as

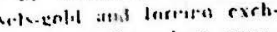
ande de rolluiersal at) accor. du. wish Nituies (ti f.7) of this l.als

in Tillat sosess mentie ird in (e) zhove stinuld ne i.. be less lian $25 \%$ of Whe ental hisbirites of $D$. A $\mathrm{B}$ with I fesal to bankno ICs in circulation.

Ainticle 0 .

Ilic assorts ef D.A.H. in rol.t consist of the follon inis

al dirols corns ald bulli. 10. la,nt. sut poids Jrposited with berenel Himls.

b) Cirlet pad in the in

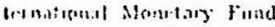
Winefl rank. Thr Asian

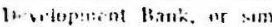
iler in-lufulions or institu tinils protaintue in thirm, a puliriasoing in lisess insti. litisise or as a sliore in the if extilis!

Amiscile?

lier fursizn raclumber auste of D.A.li. conprives of:

a) Vurcien enchangent. in thomknoter. and: thase ar.

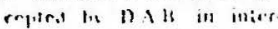

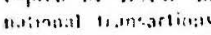

bi) liveciste curhange

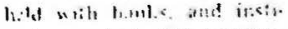

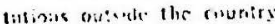

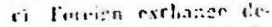
pinited with thi livi. World lintik. A ian Derel. nprintut Bink or simbiar in. stiso:mis pertuinng to in:

d) Tniritn excbante sl. siine dis. willan six monthe time.

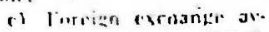
giteble nater the lapt.

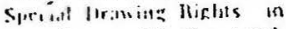
acrerdesere nitl: the segul. (1i.)

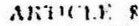

al D. Malurnictan Barh as a furernment temerpi

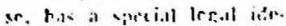
ntive, and its riche actline

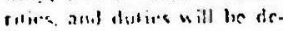
fund themoline in rules set forlh an liw law, and sted Ienolition which aty be drofled within the sone of

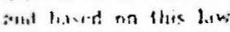

i. The leath offire of

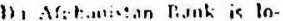
ralinl at boties.

ri II, li.. As the centr.

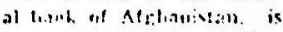
r.eirinouter for the appliea-

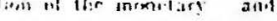

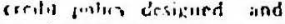

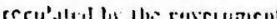

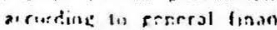

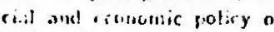
llor romerniarst

d) b.A it is cospensible to misilltain tlie valus of Afehis:l and is scroure no netary rijulibrium with vicew in furititure baukun

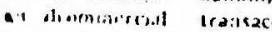
tines anel lo bilp sound renwth of orcenomis in the

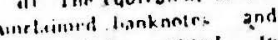

ol 7 lir rapilat of D.A.H romingeres of AL. 1.003.

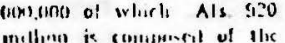

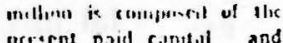
prearnt poid coptent and

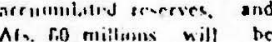

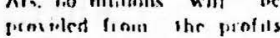

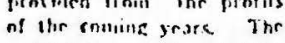
copital is riluele coveru. ment wawl. Tlir rapital call lie jurreased cienn llie reg. uret Irum llir leosid of Di. iretive. rsuinred by the Pank Jifill Conuril and ap meneil liy the (aiuncit of Ainisters.

81 D.A.l. on the basis of linstef of Mucrotus piopere sol. and sipitronal of the

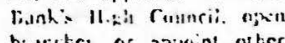
bientilies. or apioint ottier hants to rejeresont it.

c) The s.finister of rim a:ser with fo: an the link bet

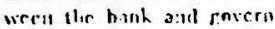
rin-al. The Mlinister of ria. ancer is authonierd to reren. late ant runtimate the finsnrial, messetry. rritii ar.d bubhine melteries of life ro untry willin the fames.

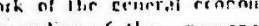
ir polisy al ther soveresti ril: Itroneh llo deparinien ts of the slinister of Finance : and I $)$ is 


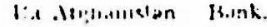

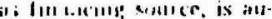
Hetsiest in idis ous the

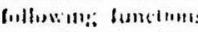

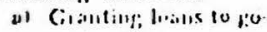
vernmernt will a vew ta insures buediset deficit

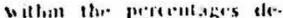

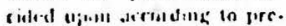

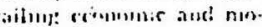

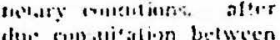

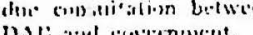

b) litanting luans fil ginernment rnterprises fill the julpases parod t, t.e :inancially

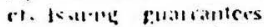

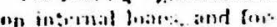
cifn bans rectiit od by ot-

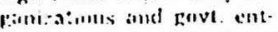
ciptistes bill bothell of the ws. when sich lo:ns biste berol proven ate ly

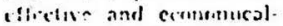
1.. anci culntilluns for than inaw ? men considercal recesang and appros cal be the linur:

d) Citsilung luats int.

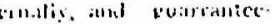

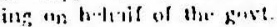

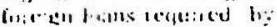
th. 1:me Merpalutios or cm.

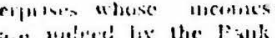

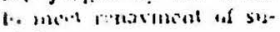
lo kisury

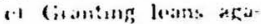

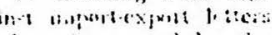

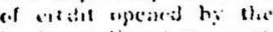

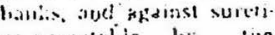
ancostatsin b: the bis:at

(1) Jumis: and s.lling

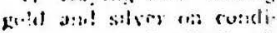

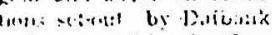

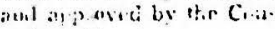
lict at Slmisicis

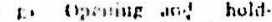

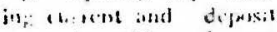
menteis with fortern

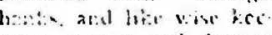

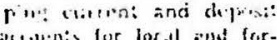
and in: Jn

(H.N.TI:H-3

AMISMISTRATHON

s): 5 ici.i. 13

1): Afidinistan bari futicicens virder the rollo vin:x simminature locel.

a) Dank Iling Conacil

u) Xivacy and Ciej:t Cimmuitere

c) Proud of Dirretests

d) Supervisory Conmit.

(1) Bataknule Reserve Spinome Curmitise

1): $1(0,5: 14$

3. HAxk Hugar cocs. cil:

Meimrlacis of lia Bank Hirh Coincil consist af the lowilewing

a) Bibsic: of finance

c) Anister of Slamning Induring

e) Ditnister of Agricul.

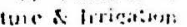

1) (iviernor at Da At rhoustion lisen (ros hav an: mets: a wat

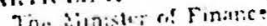

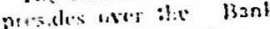
I:. h, reneneil incetines.

Al: $181.1: 30$

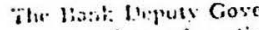
rritis, motrixes ot tre Sinvingy Conmitur. members of tire diwery

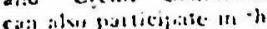
lisend: lluth Censucil mect ir ar and vitaen reguir ad $10 \mathrm{~d} / \mathrm{M} \mathrm{M}$. lank Ilich Crucils res-

1. Jin see ated diprove

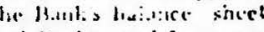
and Plutil at:d lass ac

T.) chreti the Supx colly Col..ties report

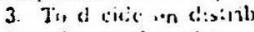
rinfi of comat patis. (11) promosing at:d repurts suldumtiod lis the Mency and C:. ci:t Colsmilter.

3. Tin ippowe ities and regulations picpured accor rdin: in tin's lat.

6. To pepso ard rer cisle un the viganzatirin and the annes! laderet of the lant:

T. Til sec to weher dulies enimisteri in litis Council of the barnk under this lav.

Mistchl: Is

Tue lickli Cinuteril of then Fank concres oudmarily 4 times atmuatlo at the end of eicle quatict. Enic crency lurbthigs will be heis at 1!." maltation of the siresister ni Fit.tuce or b. a ber. al at the for crrey of aice liant ald it ister ul rinanse.

ister it ringer

In nirer that the lligh Cruncil be alite to discus oled deced: fun cuestions pat fowar in tar agra cal at lias 3 of its nemb cis rins: lic porscist at the Nilitiol:

Decisem arebsed on a a worily of :onts of the

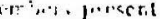

- MINA ANU CHE H1 (MIMTHE:

liatir! $1: ?$

Con and Cacit

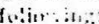

l Cosconar of jla $\mathrm{At}$. C!an:atan 1 tank

2 Picsilvit of the Tire suly. Alnistry of Finance

3 Plesident ot the Piaruera bept. Alumistry of 'incisolu:

2. Irusion: of Forcign

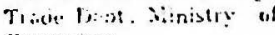
Conmentes

3. Pirsicient of the Cha ntwer of Conutnctec a

6. Tiso Cusemos of bante flamed by the Mini ster of Finence

:. Cir biatiag sjecial. st illa karuliv of Fintoinits, Kutul Univ

:* W! Dewuty Gin:c:rent, Da AfLinatas!an llank

\section{1) $1.2 ; 29$}

Jlse croverner octs as chatrman and abe davectar

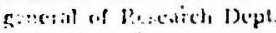
of llik! a the secicting of the Conanitte for dio n' $\because$ and Cirdit.

METHCIE: 23

This diaser and Cirdit Commitlec will be nespo Instbie fur tha fotisuing functings:

my atdd cist: wil! con

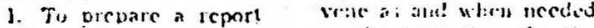
on hans revuires by the Enit stith enlerprises. and numeigalles for sto lawionis lil thr

? T. mepac rmant un

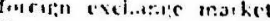

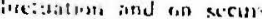

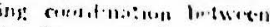
live Putyes axchange pos]. cy" shad tla: providant ec

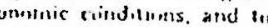
outmai! Hacm lo blir lligh.

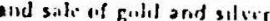

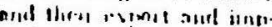

4. To propore introws

ialies on vicpessils sint

5 Tu preprose the niaxi mum, und minimum rate ing seviers to the lligh Coucil.

6. Tit draft rules and requldiums an ker.ul borik therives and to submit tor apperol.

i. Tin morese lo the High Conncil the wavs of utliziol: curent and dep mit funds and atlise funds
placred at lise disposal ef placred at

f. To roense the ratio helwech futal sivh ho!d inas and tolal acils ag ainet tutil bablutities of the banks

cen bitte the cation! and hank reserves and firms of exsols lietel bo brants.

10. Tn picpore ratin bc ctoren visnictiale and bial:s an's theil cas dit dep.r

11. Tw aride on the Innu dif lablance slicel and prolit and bess acciunts of

12. Tu formiulate prines. 1.3. To lese:andh and pr. cprece the cxicition pre

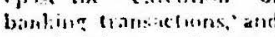
protutarizing: ereviatien of binds and guvt. Juan certificates.

14. To sousl: cotisi.

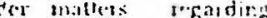
mency ated cordit. and foren cxoldtenac, and 10 lliph Cinumel on these istion the the law and suthittinr. them In the llit:te Commi

Tin "riptess view en hankind. matrity ard cre and on rules and lowis reiment lo trentme luans onj guasinfers, and cther muncy ard banking c.mintla be the Ninisier al Finance

17. Ta submit advisum view In the ravt though 1!: Slumster of Finatice. on bialinat. nwher. and convielcied by the commi lien eflective te, the cco temin: and speciatly in th: cicdit pilies.

18. Ti express view an malteds stilunilled fit the Commitus by the licsid

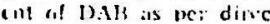
tiv...; a.t felth in this law. Al:TICI.1, 24 cat the invitatern

Cowrenes th t?

in ariter to camsare the silin? and credel rommi there at baist 7 mombers mist for poustet

Alli!ci.1. 26

The decisings ore reach at be the usury and cie dit conmatllec when they orecine the support of the mitinity of the vutes cast al thectings. sits with Da Aluhanistan

is To druft rulcs and re.

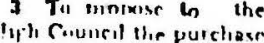

2. ImIItO OF DHur. Alilite: 27

I. Tire bleard of Dirces 


\section{Anticit: 13}

1. litolh 1 an insletuliun

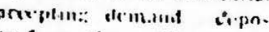
its fium the pulitic lor lle purpuse ol frucime or in.

2. Hijnsils nialy under (I) "I thiv pustersith are

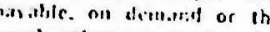
ratch other niethocs. by rhequer, Iralleser atud oude: ric.

3 liank by atseh nieatis the uffire or olfises where de posits ar arcroped. che quir caclied. luans aranted. (Ievirtions under i a ? ab ove are impleniented).

4. Willant cinposis are dcbits p.ts.th? on sirniand, wilike tune depusits arc not pisalte on demiond.

5. Citaminerd forns. are

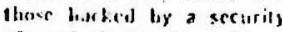
of rguisulent valur. tiner. curitl. or piltererumed let atis ate not tursonted it the itasise form.

6. Cilledared securitirs

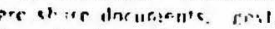
Inm bonds, and croasusy bund. issued by the revern ment or specialied lianks unuter the provisions of untier the

i. Cisld umrans gold niprted on lations

CoNb!?IONS TO ISTAB

l.1. I:1135

AlTISI.F: it

I. In entalibsh touk

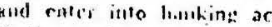

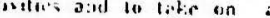

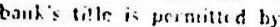
the dulce:ives of thes law:

2. The lowking artisisies

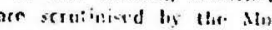
wiy and Cicin Coumnitle. Sucli in invities are prom itted orit aller the aup

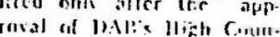
ril.

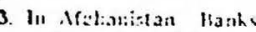

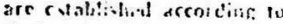
lheri mirjitred statuice of

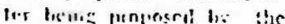

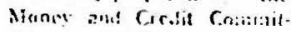
ime. anmowerl be the ba Aribonisan liank llah ro

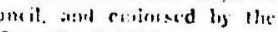
rnukil of leniciers.

\section{Ariticit: 4s}

Cinenre or omenime of the bink. beanrhes an the so untry or ithersal is suleject

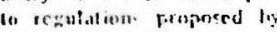
Nlansy and erolet Comme ille. anl aistured hy

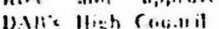

Al:meril: si;

III Nichan:tan the cap ilal of life hionks is nue fumbed per rom batiottol i.r state-nwind.

Alaticil: 47

the banhs alreally operditiz in the counters. whose statutes difter fiom the dirctires of the low. are enquiseal in a amerid therer stitules accordinat to the provieiens of this liw, within a maxitnum perind of une year aller line promulgation of llais law. bave threm rudiessed by llie bites High Council ant

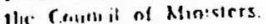
Altites, 48

Tly. minimina coppital of ledik in Mikhunislal is Ak. :0 millimns.

\section{Alizicle: 49}

The cowctunent purcle. oxes all hast: sladers within limen entereced

Alldili: in

1 The hink a copltal is povilile in land curicute

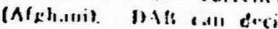
de sil the devilline fer for. inent of the fromined a

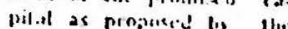

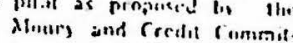
tor and appoured by the

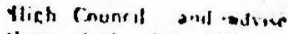

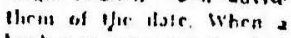
b.ink r.tu out luect the di.2. dline lais powneent of ther minilseril ropatol otep n.it e. tahen lis linguilate it. 2. The li,anhs ravitial is ierresud by piogusal of

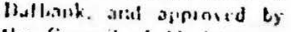
the Comuril of Vumisers. CHAl'HS 2

WHTI!C) (I HANKIAC Fi:nerloms

1. Mll b.like are erquired to Ir.m-lite at Ir.jes, is per cout of their nel pirofies

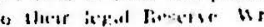

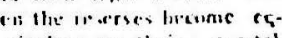
vivalevel to their rapital thiv transfer lenesumess opti. onsl.

2. Deprecistion of red cstule allit numble pingert are r.ileulatest. and arcoun

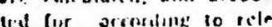
vane reculations:

3. Bautivare required 10 have threir balauces and pre. ofit and lises acmulis rxanind ly gituliors lohirte re.l accomenturest m!ficisiti rensered in . Nofhomst an

4. Thr linir for. and thr nilimerer of herpune tise rernols and dicurents ejllier, lil oricenial farin or 2 : photustels. of litui. W.:.

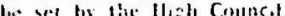
as propaced la llar Mancy arid Cercht Comunitser Sa. cl: phoinstist and filnis 2 ? li.r expiry of deffinier perleds ol time are enneidered by rourts of justice. 2s oricina?

5. Ao bart: cau pay da iiluse to vinctiniders un leas is tian shituly comine sated fer sil of its colaltis? tillul ansts, s:Imenisstuti. ixpellers. coulingenty ins 50. lus to the clis. in slus. whes bisl debts incorte

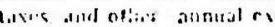
pendilures and has acrum alitcil suffiricha orsern. againal nombeal credils

C. Prier In espory of nac sear from llec inplementi tion of th: 1,a., all t,as:

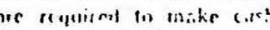

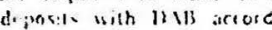
int to the refothtions s.." fusth fus the purporer. a:

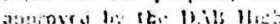

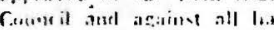
bilitirs errardiag fixel fitale

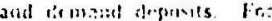

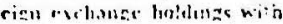
forizen lionhe de nell es heldinite in ancens of cas

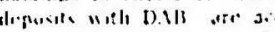
retitiled in past of the sh orc nethitsird linidine

7. Withenever necessas an arfminieteative and ac rourts investientinn of the

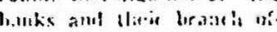
fires witl he untertithen in orroret.nct with the cirrec: ce of the law be ba

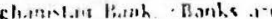

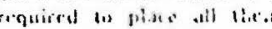
berche. aromute, snd docur

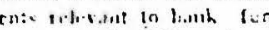

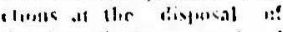
the meroticsters as did When dionsonded lis tir

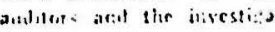

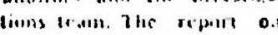

Sulf thersaticetinus is to:"alded big lidls to thr lite

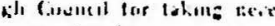
cess devinus.

coliflian 3

HWh' HIIT

Alliti.1.1: t:

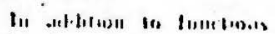
defored zusdits Artacie ti

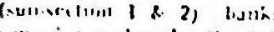

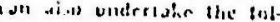

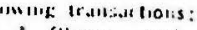

1. Ollüll dild exicid

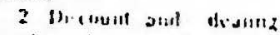
nill deats ant vilive 站 durinneuts.

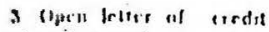

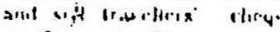

A. lins 2ant seil forcion

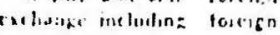

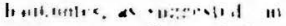

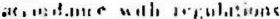

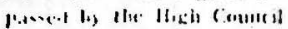
al WW:

s site crestall of oricin.

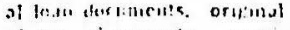

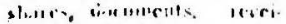

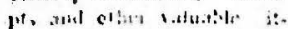
rote wat innvile s.lfe de.

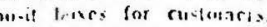
c. leelortio tove and b.

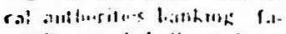
riblire an l,.talf o! Delti.

i fatr nal alls funti-

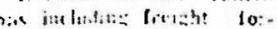
watem: and ciesrancr for chince

a. Sitl sreursties on be-

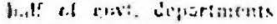

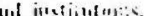

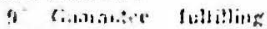

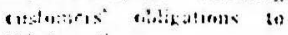
thise p.titim

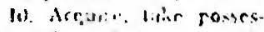

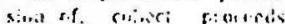

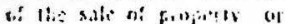

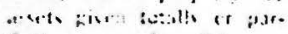
(1)

11 A.quare tetie pors...

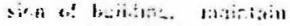

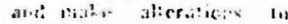

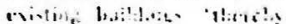

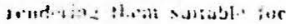

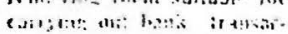
ian

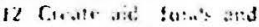

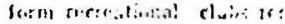
libe resplaseris.

15 9.8.

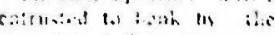

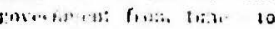
I:I:I"

\section{rlivitis}

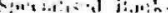

A.Mrimle :-

1. A riansined loting is

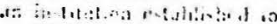

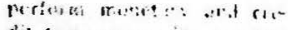

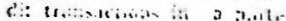

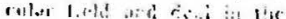

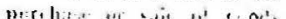

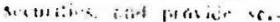

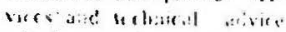

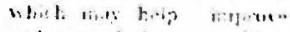

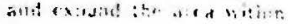

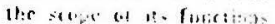
$\Rightarrow$ A tulat

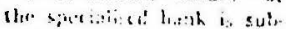

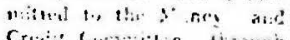

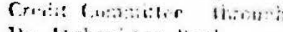

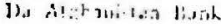

3. Jire tamsori pasm.

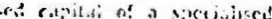
bath should be the ov milivin

4. A spreculised bunk is

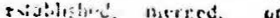
clused car lite proposal of ta: Verom and Cercris Cer mathlle. contrianturn of Da Ningnim lintik and

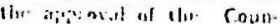
cit of Minisuets. 
A!zut:: :

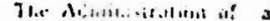

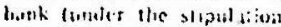
at Arikite sol and form at

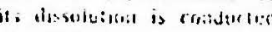

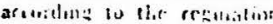
drawn 1:a liy the Mune.

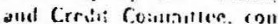

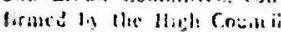

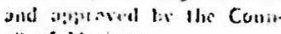
(it) n! Mnialds

dhitides as

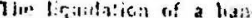
krugri busit is ctiousted lo

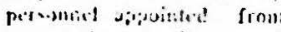
s:ame: lin miphers of Hiat buthe. under the sua

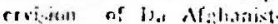

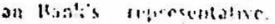

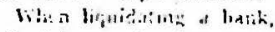
all eluines of drpes:tes:

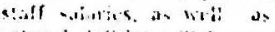

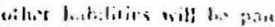
fonin lir. ancets of irot but

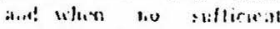

fund is actistes the for rentlinnt will lacthe wip for crnand will lather lib for

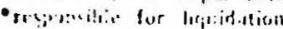
a! the tiult. submets tam. thly ingart to tire

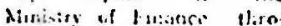

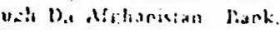
The lawisery of risulfe on

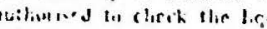

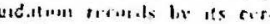
titiod ar:tatu: ind inwesti.

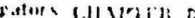

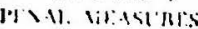

\section{Alstikild :ol}

1 fincis: in sellowe for

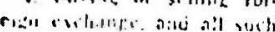

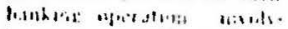

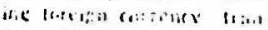

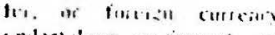

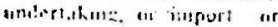

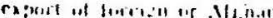

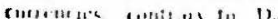

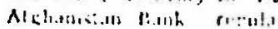

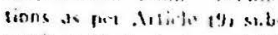

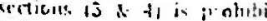
ted

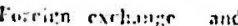

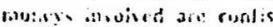
reici a and viulaten:e persuns

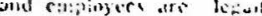
pruaccular did punishoud

II llo villense is repedied

in atditio: 10 confuction

a furc of 25 pir cint of

the whw is mused and

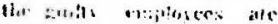

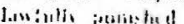

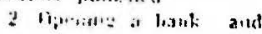

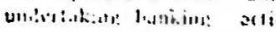

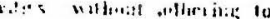

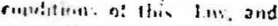
tont: the rend liste in

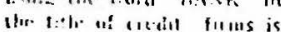

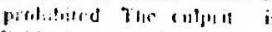

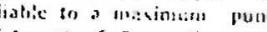

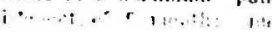

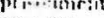

- Nitil.

Cimund and justrinl ac

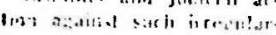

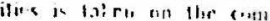

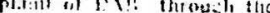

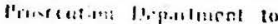
Bhe releteri atuats

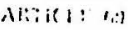

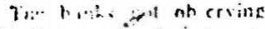

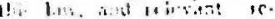

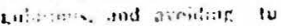

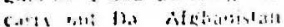

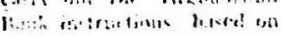

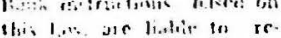

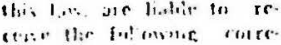

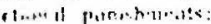

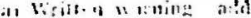

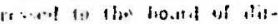
win.

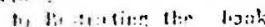

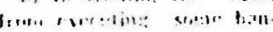

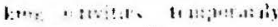

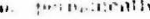

li... ansor vhish ran

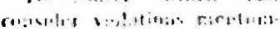

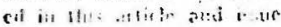

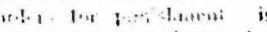

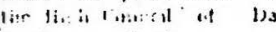

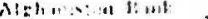

(11.4.1) 9

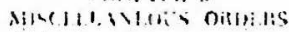
Al:11:11. 01

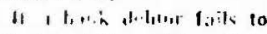

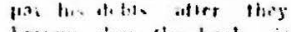

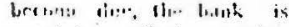

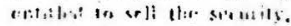

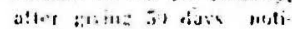

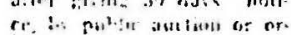

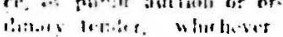

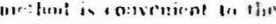

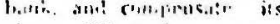

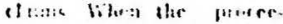

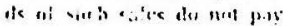

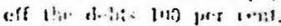

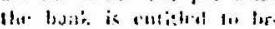

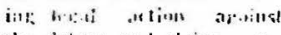

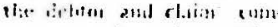

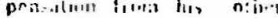
acerle 71.0 metice will be

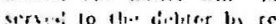
r. . .

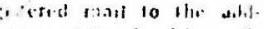

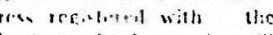
Jrumes lisath, and will

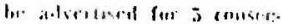

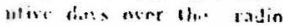
oris in a... of ther Incot:

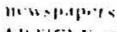

Altirit:

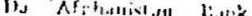
vilf dats bet verulations

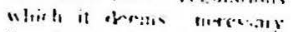

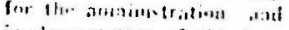
inglemencustion of this law. ARTirl.t: 6.5

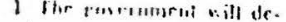

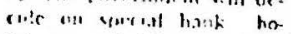

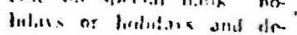

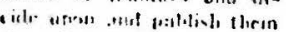

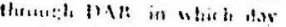
or thes ll: bouk will post corrs west babne" transa.

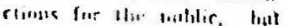

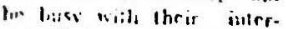
"u.l allitirs.

2 Ther lombs will be up

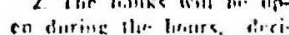

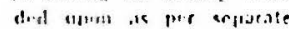

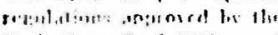

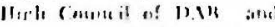
rarrs nut fazkine trancar. liturs lies tlar bulitu.

3) Tly forergement will

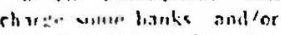

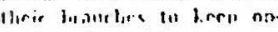

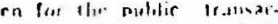

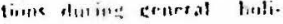
diac

+ lluries whirb enpuire

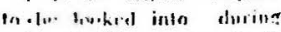

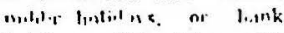

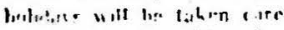
al on l/ir l.1 wroking das folimener sath halitess.

lellict 1.1

Tlios lail linenme rlierii.

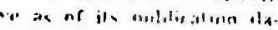

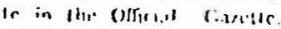

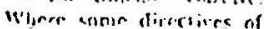
nllier liaws ner remirary to thie mis. bhe dirertives of

thiv are applicaster.

(ins?) 